\title{
Potential Pathways of Abnormal Tau and $\alpha$-Synuclein Dissemination in Sporadic Alzheimer's and Parkinson's Diseases
}

\author{
Heiko Braak and Kelly Del Tredici \\ Clinical Neuroanatomy Section/Department of Neurology, Center for Biomedical Research, University \\ of Ulm, Helmholtzstrasse 8/1, 89081 Ulm, Germany \\ Correspondence: heiko.braak@uni-ulm.de
}

Experimental data indicate that transneuronal propagation of abnormal protein aggregates in neurodegenerative proteinopathies, such as sporadic Alzheimer's disease (AD) and Parkinson's disease (PD), is capable of a self-propagating process that leads to a progression of neurodegeneration and accumulation of prion-like particles. The mechanisms by which misfolded tau and $\alpha$-synuclein possibly spread from one involved nerve cell to the next in the neuronal chain to induce abnormal aggregation are still unknown. Based on findings from studies of human autopsy cases, we review potential pathways and mechanisms related to axonal and transneuronal dissemination of tau (sporadic AD) and $\alpha$-synuclein (sporadic PD) aggregates between anatomically interconnected regions.

Sporadic Alzheimer's disease (AD) and ParSkinson's disease (PD) are human neurodegenerative disorders that do not occur in other vertebrate species. Pathological hallmark lesions in $\mathrm{AD}$ and $\mathrm{PD}$ involve only a few types of nerve cells, mainly projection neurons. These lesions develop at predetermined predilection sites and progress according to predictable patterns (Braak and Del Tredici 2009, 2015). In AD, disease-related lesions remain confined to the central nervous system (CNS), whereas in PD they develop not only in the CNS but also in the enteric (ENS) and peripheral (PNS) nervous systems. Both diseases are caused by misfolding of specific proteins that are associated with aberrant aggregation. $\mathrm{AD}$ is primarily characterized by pathological forms of the intraneuronal protein tau (Goedert et al. 2006; Iqbal et al. 2009) and, thereafter gradually, by extracellular deposits of the $\beta$-amyloid protein (A $\beta$ ) (Alafuzoff et al. 2009; Haass et al. 2012; Masters and Selkoe 2012). In mature nerve cells, the highest concentrations of the protein tau usually are found in the axon. Key lesions in sporadic PD consist of aggregated forms of $\alpha$-synuclein, a protein located chiefly in axons and their presynaptic terminals (Eisenberg and Jucker 2012; Jucker and Walker 2013; Kaufman and Diamond 2013; Goedert et al. 2014). Notably, all brain regions and all types of nerve cells consecutively involved in AD or PD are anatomically interconnected over considerable distances, thereby indicating that physical contact among such interconnected nerve cells plays a

Editor: Stanley B. Prusiner

Additional Perspectives on Prion Biology available at www.cshperspectives.org

Copyright (C) 2016 Cold Spring Harbor Laboratory Press; all rights reserved; doi: 10.1101/cshperspect.a023630

Cite this article as Cold Spring Harb Perspect Biol 2016;8:a023630 
key role in the pathogenesis of both illnesses (Pearson et al. 1985; Saper et al. 1987; Pearson and Powell 1989; Pearson 1996; Duyckaerts et al. 1997; Braak and Del Tredici 2011b). A $\beta$ is deposited extracellularly and thus is not known to transfer from one nerve cell to the next in the neuronal chain (Fiala 2007; Kaufman and Diamond 2013).

Here, we focus on potential pathways and mechanisms related to the postulated transmission and transneuronal dissemination of tau and $\alpha$-synuclein between involved neurons and as yet uninvolved neurons in anatomically connected regions (Brundin et al. 2008, 2010; Clavaguera et al. 2009, 2013a,b; Desplats et al. 2009; Luk et al. 2009; Angot et al. 2010, 2012; Frost and Diamond 2010; Goedert et al. 2010; Lee et al. 2010; Nonaka et al. 2010; Dunning et al. 2011; Guo and Lee 2011, 2014; Hansen et al. 2011; Jucker and Walker 2011; Kordower et al. 2011; Lee et al. 2011; Volpicelli-Daley et al. 2011; Hansen and Li 2012; Holmes and Diamond 2012; Liu et al. 2012; Luk et al. 2012a,b; Mougenot et al. 2012; Polymenidou and Cleveland 2012; Walker et al. 2012; Duyckaerts 2013; George et al. 2013; Iba et al. 2013; Masuda-Suzukake et al. 2013; Olanow and Brundin 2013; Rey et al. 2013; Van Ba et al. 2013; Wu et al. 2013; Ahmed et al. 2014; Dujardin et al. 2014; Holmes et al. 2014; Holmqvist et al. 2014; Recasens et al. 2014; Calafate et al. 2015).

Nerve cells that survive and remain functional for the lifetime of an individual are capable of degrading and eliminating defective proteins and/or toxic metabolites. Thus, the presence of pathological intraneuronal aggregations of tau and $\alpha$-synuclein is an unusual and unanticipated event. The misfolded and initially slightly aggregated forms of both proteins rapidly transform into insoluble inclusion bodies: in $\mathrm{AD}$, neuropil threads (NTs), pretangles, neurofibrillary tangles (NFTs), and ghost tangles; in PD, Lewy neurites (LNs), pale bodies, punctate aggregates, and Lewy bodies (LBs) (Ikeda et al. 1978; Grundke-Iqbal et al. 1986; Gibb et al. 1991; Dale et al. 1992; Spillantini et al. 1997; Goedert et al. 1998, 2013; Braak et al. 1999, 2006; Kuusisto et al. 2003; von Bergen et al. 2005; Dickson et al.
2009; Parent and Parent 2010) that occupy space and remain nonmetabolized in involved neurons without, however, initially recognizable toxic effects (Braak and Del Tredici 2009, 2015a).

Projection neurons generate a long axon to transmit information from one site to another. For this purpose, their axons have mechanisms for anterograde and retrograde transport of various cargos. However, they are not especially well equipped to degrade or eliminate pathological proteinaceous aggregates (Braak and Del Tredici 2009, 2015a). Moreover, because of the major differences between the axonal and the somatodendritic compartments, the mechanisms by which axonal compartments manage misfolded and aggregated proteins merit closer study. During AD pathogenesis, hyperphosphorylated tau proteins that lie free in the cytoplasm of vulnerable nerve cells undergo a change of conformation and become slightly aggregated. Initially, these soluble proteins are uniformly distributed in both the somatodendritic and axonal compartments. These proteins gradually become less soluble until, having become confined solely to the somatodendritic compartment, fibrillar structures develop and a pronounced argyrophilia emerges. In contrast, these additional steps are missing in axons (Braak and Del Tredici 2015a).

In other words, pathological tau in the axon is processed differently than in the soma, and it remains in the axon for a longer period of time in a gel-like, nonfibrillar, and nonargyrophilic state. It is conceivable that, under these circumstances and possibly only for a short time, soluble aggregates of misfolded and hyperphosphorylated but nonfibrillar tau protein penetrate as far as the terminal branches of the axon and into presynaptic terminals, where they then become available for transport to the postsynaptic side of the synaptic cleft (Braak and Del Tredici 2015b). Were that to prove true, the pathological process would be transmissible to the successive neurons only via terminal axons and synaptic connections of involved nerve cells.

These considerations and experimental data make it possible to associate the $\mathrm{AD}$ - and $\mathrm{PD}$ - 
related pathological processes with $\operatorname{PrP}$ prion diseases (Prusiner 1982, 2012, 2013; McBride et al. 2001; Vella et al. 2007; Aguzzi and Calella 2009; Aguzzi and Rajendran 2009; Guest et al. 2011; Liberski 2012; Herva and Spillantini 2015). However, we prefer to use the term "prion-like" to differentiate sporadic AD and PD from rapidly progressive and infectious prion diseases, as $\mathrm{PD}$ and $\mathrm{AD}$ have not been shown to be rapidly progressive and contagious (Olanow and McNaught 2011; Iba 2013; Irwin et al. 2013; Kaufman and Diamond 2013; Beekes et al. 2014; Goedert et al. 2014, 2015; Brandel et al. 2015; Walker and Jucker 2015; Walsh and Selkoe 2016). Available evidence from experimental studies performed in animal and in vitro models indicates that misfolded tau and $\alpha$-synuclein proteins fulfill the criteria of prionlike proteins, that is to say, seeding/templating, propagation ("spreading"), and structurally differentiated conformations or conformers ("strains") (Aguzzi 2009; Clavaguera et al. 2013b; Guo and Lee 2011; Bousset et al. 2013; Watts et al. 2013; Sanders et al. 2014; Melki 2015; Peelaerts et al. 2015; Smethurst et al. 2015; Woerman et al. 2015; Tuttle et al. 2016; but see also Bernis et al. 2015; Prusiner et al. 2015; Supattapone 2015).

\section{SPREAD OF PATHOLOGICAL TAU LESIONS IN AD}

In $\mathrm{AD}$, pathological tau aggregates develop first in nerve cells of brainstem nuclei (subcortical stages a-c) (Figs. 1A,B and 2, dark blue) that have projections ending in the cerebral cortex (Braak and Del Tredici 2011a, 2015a,b). It appears that from the locus coeruleus of the pontine tegmentum (Marien et al. 2004; AstonJones and Cohen 2005; Samuels and Szabadi 2009; Sara 2009; Counts and Mufson 2012; O'Donnell et al. 2012), the lesions progress to a distinct portion of the cerebral cortex, the transentorhinal region (Figs. 1 C,D and 2, light blue) (Braak and Braak 1992). In cortical projection neurons, the resultant and originally nonargyrophilic pretangle protein (during cortical stages $1 \mathrm{a}$ and $1 \mathrm{~b}$ ) becomes transformed into argyrophilic neurofibrillary lesions that
Tau and $\alpha$-Synuclein Dissemination in AD and PD

characterize the subsequent NFT stages I-VI (Braak and Del Tredici 2015a). The neurofibrillary pathology advances from the transentorhinal region (NFT stage I) (Fig. 2, light blue) into the olfactory bulb (OB) (Attems and Jellinger 2006), the entorhinal region, and the hippocampal formation (NFT stage II) (Figs. 1D and 2, dark red). During NFT stage III, the tau pathology progresses from the transentorhinal region to the laterally adjoining basal temporal neocortex, and during NFT stage IV, it extends more widely to the temporal, insular, and frontal neocortex (Figs. 1E, 2, light red, and 3A,B). In NFT stage $\mathrm{V}$, cases display severe involvement of most neocortical association areas, leaving only the primary fields mildly involved or intact (Figs. 1, 2, dark pink, and 3C). In the end-stage, NFT stage VI, even these areas become involved (Figs. 1, 2, light pink, and 3D). The production of abnormal tau continues from the outset until the final stage of the pathological process (Braak et al. 2011; Braak and Del Tredici 2014, 2015a). Thus, in $\mathrm{AD}$, the pathology progresses anterogradely from distinct predilection sites in the lower brainstem to distant but connected regions of the cerebral cortex, and it does so sequentially with little inter-individual variation, albeit at different rates (Braak and Del Tredici 2015a).

The locus coeruleus and other widely projecting subcortical nuclei share a remarkable attribute: All of them send long and extensively branching projections to the olfactory bulb and the entire cerebral cortex, to large numbers of other noncortical nuclei (with the notable exception of the pallidum), to the cerebellum, and to the spinal cord. These widely projecting noncortical nuclei are collectively referred to as "nonthalamic nuclei with diffuse projections" and include not only the noradrenergic locus coeruleus but also the serotonergic nuclei of the raphe system, the extranigral dopaminergic nuclei of the mesencephalic tegmentum, the histaminergic hypothalamic tuberomamillary nucleus, and the cholinergic magnocellular nuclei of the basal forebrain (Nieuwenhuys 1996). A prominent feature of primate evolution is the considerable increase in the size of the cerebral cortex, particularly of its neocortical por- 
H. Braak and K. Del Tredici

A

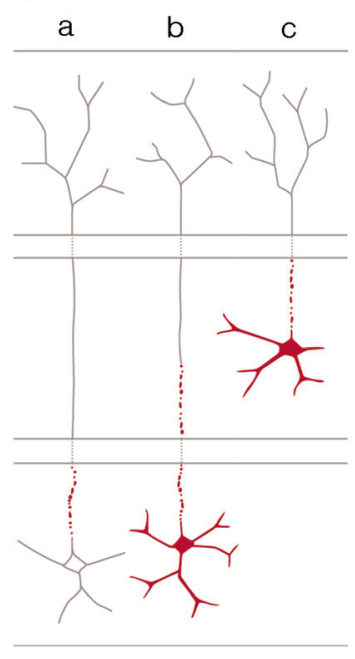

D Stages 1a, 1b, I-II

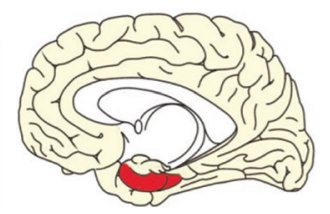

B

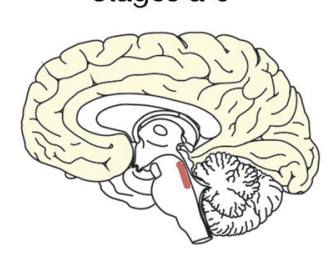

E Stages III-IV

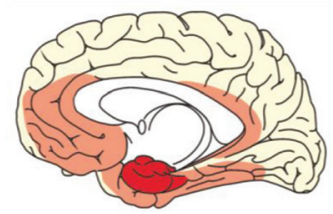

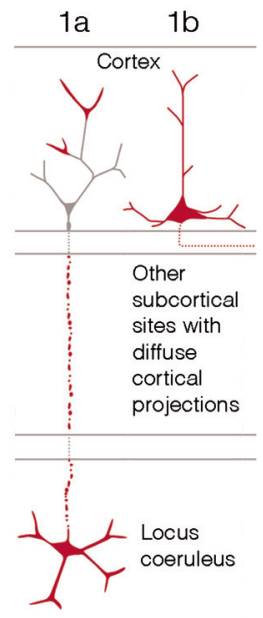

$\mathbf{F}$

Stages V-VI

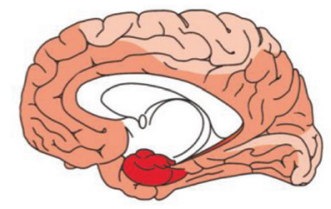

Figure 1. Are small aggregates of pathological tau proteins transmissible in Alzheimer's disease (AD)? Summary of the stages of AD-related tau pathology (subcortical stages a-c, cortical pretangle stages $1 \mathrm{a}$ and $1 \mathrm{~b}$, and cortical neurofibrillary stages I-VI). (A) Axons of projection neurons of the locus coeruleus are the first structures to develop pretangle material immunoreactive against hyperphosphorylated tau protein (subcortical stage a). This aggregated material then fills the somatodendritic compartment (subcortical stage b). In subcortical stage $c$, additional nonthalamic nuclei with diffuse cortical projections (i.e., the upper raphe nuclei or the cholinergic magnocellular nuclei of the basal forebrain) begin to display pretangles. $(B)$ The AD-related pathological process is confined to subcortical nuclei during stages a-c. $(C)$ In pretangle stage 1a, pathological material develops in portions of nerve cell processes ( possibly pathologically involved terminals of axons from the locus coeruleus) in the transentorhinal region of the cerebral cortex. This material subsequently fills pyramidal cells in the transentorhinal region ( pretangle stage $1 \mathrm{~b}) .(D-F)$ Drawings depict the systematic dissemination of the AD-related process from cortical pretangle stages $1 \mathrm{a}$ and $1 \mathrm{~b}$ and neurofibrillary tangle (NFT) stages I and II (dark red) to neocortical high-order association areas at NFT stages III and IV (light red) and, finally, to first-order association areas and primary neocortical fields in NFT stages Vand VI ( pink). (From Braak and Del Tredici 2013; reprinted, with permission.)

tions. As such, all of the nonthalamic nuclei also developed phylogenetically late-appearing and ontogenetically late-maturing components that were necessary to support their strong projections to the cerebral cortex (so-called "integrated phylogeny”) (Rapoport 1988, 1989, 1990, 1999).

The axons of all of the nonthalamic nuclei have an additional property in common- namely, the presence of nonjunctional varicosities equipped only with presynaptic sites that are supplemented by relatively few classical synapses with both presynaptic and postsynaptic sites (Agnati et al. 1995; Nieuwenhuys 1999; Marien et al. 2004; O’Donnell et al. 2012). By means of nonjunctional varicosities, axons release their neurotransmitter and neuromodulator substances diffusely into the interstitial 


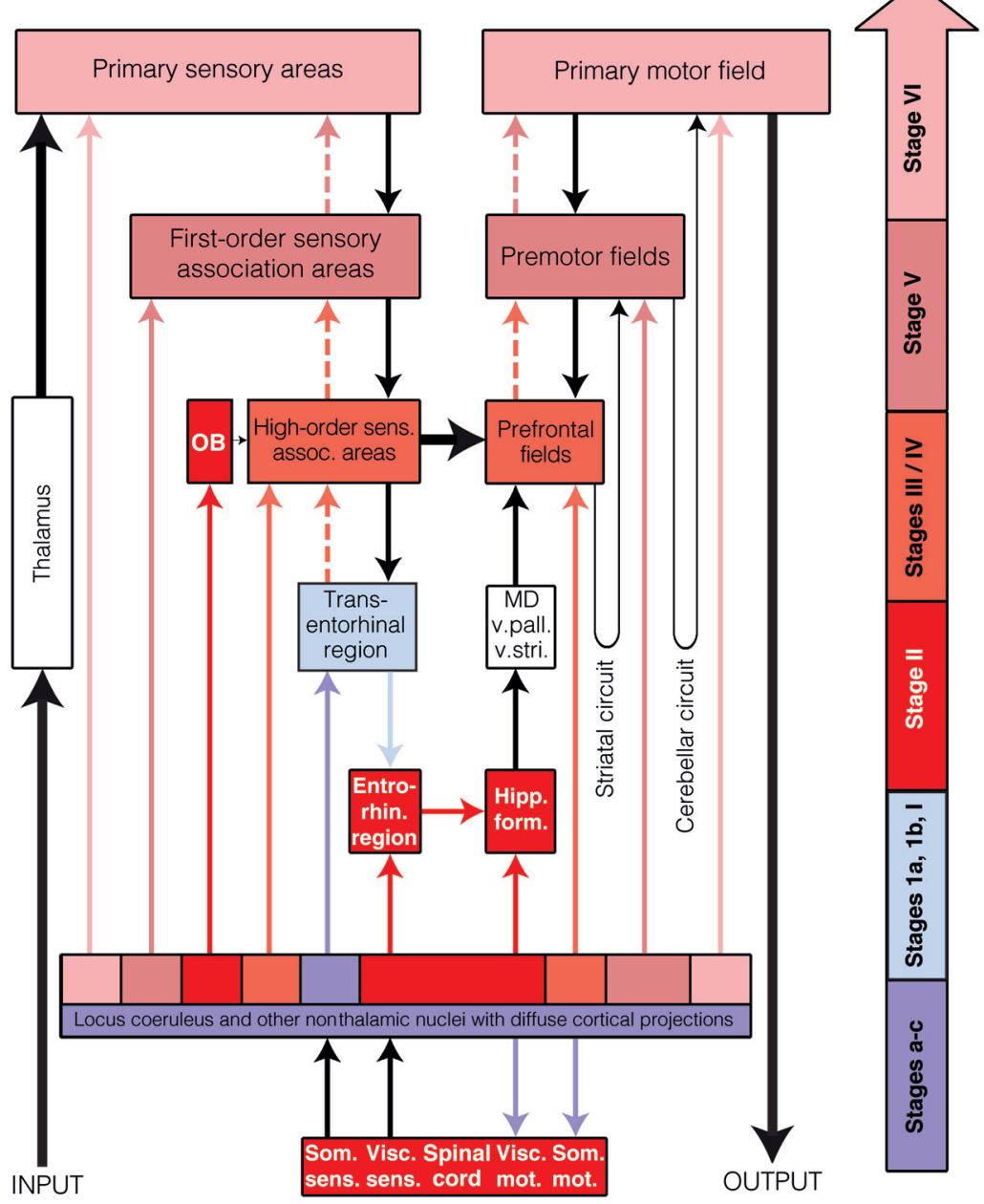

Figure 2. Possible routes of tau transmission in Alzheimer's disease (AD). The color-coded arrow at the right indicates $\mathrm{AD}$ neuropathological stages a-VI and $\mathrm{AD}$-related lesions. Color-coded arrows (excluding black arrows) are intended to indicate the routes by which the intraneuronal tau pathology may consecutively disseminate by anterograde transport. Directly above the block containing the locus coeruleus and other nonthalamic nuclei with diffuse projections to the cerebral cortex is a multicolored row: It is intended to signify the different groups of nerve cells belonging to these nuclei that become involved at various Parkinson's disease (PD) stages. OB, Olfactory bulb (chiefly the anterior olfactory nucleus); entorhin. region, entorhinal region; highorder sens. assoc. areas, high-order sensory association areas; hipp. form., hippocampal formation; MD, mediodorsal nuclei of the thalamus; som. mot., somatomotor; som. sens., somatosensory; visc. mot., visceromotor; visc. sens., viscerosensory; v. pall., ventral pallidum; v. stri., ventral striatum.

fluid by volume transmission, in a paracrinelike manner, thereby activating receptors of glial cells, neurons, and cells of the vasculature within a given local diffusion zone (Kalaria et al. 1989; Agnati et al. 1995; Marien et al. 2004; Fuxe et al. 2012; O'Donnell et al. 2012). The mechanisms of volume transmission are ill suit- ed to relay data in a highly selective manner from one site to another. Their effect is more generalized (Morrison et al. 1982; Fuxe et al. 2012). In contrast, complete (classical) synapses produce highly selective localized effects. It is unknown how nonjunctional varicosities and complete synapses are distributed along the 
H. Braak and K. Del Tredici

A

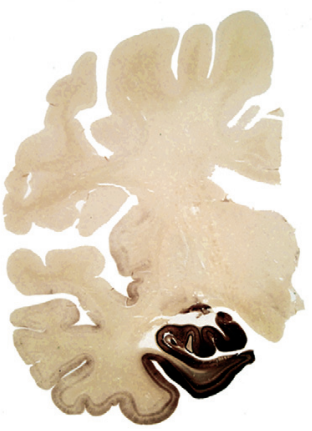

AD NFT III

C

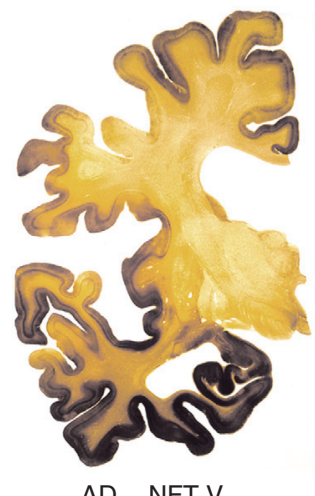

E

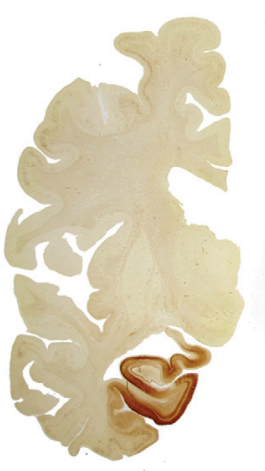

AD/PD NFT III
B

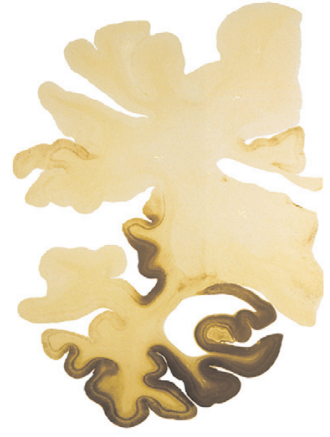

AD NFT IV

D

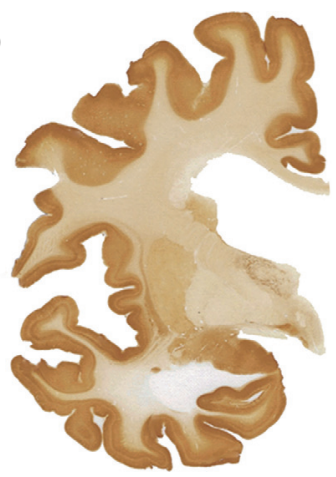

AD NFT VI

$\mathbf{F}$

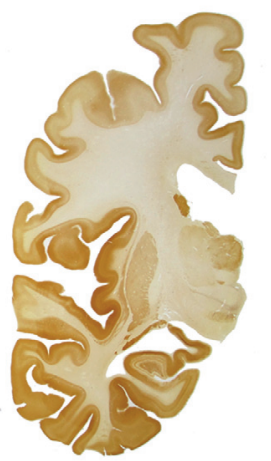

AD/PD stage 6

Figure 3. Neurofibrillary tangle (NFT) stages III-VI of sporadic Alzheimer's disease (AD) in $100 \mu$ m polyethylene glycol-embedded hemisphere sections. $(A-D)$ During the limbic stages III and IV, areas of the anteromedial portion of the temporal lobe, including the transentorhinal region, entorhinal region, and hippocampal formation, become severely involved. From the transentorhinal region, the tau lesions enter (moving clockwise) into the adjoining high-order sensory association areas of the temporal neocortex (stage III) and from there into the medial temporal gyrus (stage IV). The insular cortex also becomes involved (stage IV). At neocortical stages V and VI, the premotor and first-order sensory association fields of the neocortex, and thereafter, the primary fields of the neocortex including the transverse gyrus of Heschl, develop very severe tau pathology. (E,F) Note that the transentorhinal region and the adjacent temporal allocortex are highly susceptible to both sporadic Parkinson's disease (PD) and AD. $(A, B, D, E)$ AT8 immunohistochemistry, $(C)$ Gallyas silver-iodide staining, and (F) $\alpha$-synuclein immunohistochemistry. 
heavily branching axons of the widely projecting nonthalamic nuclei, but we are inclined to believe that nonjunctional varicosities do not play a major role in the neuron-to-neuron transmission of abnormal tau, and, instead, precisely localized one-to-one effects take place chiefly via complete synapses.

The majority ( $20 \%$ ) of locus coeruleus efferences remain ipsilateral (Marien et al. 2004). The AD-related pathological process begins ipsilaterally in the locus coeruleus in young adulthood or even in childhood (Braak and Del Tredici 2011a) and later involves coeruleus neurons on the contralateral side of the brain and neurons of other nonthalamic nuclei with diffuse cortical projections (German et al. 1992; Benarroch 2009; Sara 2009). The noradrenergic neurons in the locus coeruleus do not all become involved simultaneously: Abnormal tau inclusions appear first within a few neurons, and additional neurons very gradually follow suit. The continual increase in the number of involved coeruleus neurons occurs so slowly that noninvolved nerve cells are seen there even in advanced $\mathrm{AD}$ cases. Hence, the locus coeruleus does not undergo extensive nerve cell loss during $\mathrm{AD}$, and this lifelong process within the coeruleus is possibly not fortuitous but predetermined.

It is possible that the pathological process within the locus coeruleus initially involves only those nerve cells that represent the most recent evolutionary events in the course of the phylogenetic process, and, accordingly, these same nerve cells are the last to mature ontogenetically (Fig. 2, dark blue). As a result, however, it may also be assumed that these coeruleus neurons send their ipsilateral projections to portions of the cerebral cortex, which from an evolutionary standpoint, developed very recently (Fig. 2, light blue). In this context, it should be noted that the transentorhinal region functions as a new interface between the phylo- and ontogenetically late-developing basal temporal neocortex and the entorhinal region, which in microsmatic primates, is preferentially neocortically oriented. In the ascending primate line, the transentorhinal region greatly increases in size, and its topographical extent peaks in humans (Braak and Braak 1992). Thus, the most recent "acquisitions" of the locus coeruleus are likely to be the nerve cells that develop in tandem with the transentorhinal region and project to that region. These circumstances may help to explain why the two neuronal types that are located at a considerable distance from each other (coeruleus neurons and transentorhinal pyramidal cells) consistently develop the earliest $\mathrm{AD}$-related tau lesions within the CNS as a whole (Figs. 1A,C and 2, dark/light blue) (Braak and Del Tredici 2011a, 2015a,b). Furthermore, this would imply that the neurons in the locus coeruleus that mature phylo- and ontogenetically earlier send projections to their earlier maturing counterparts in corresponding portions of the cerebral cortex (see color shading of both the nonthalamic nuclei and their cortical projections in Fig. 2), and, in fact, the lesional pattern that develops during the course of the $\mathrm{AD}$-associated pathological process reflects the fundamental phylogenetic developmental phases of the neocortex very closely: The primary areas there appear first, and these are also the first to myelinate. The primary areas are followed by secondary fields and, thereafter, by high-order association fields. This process culminates in primates with the appearance of the transentorhinal region, which acts as a transitional cortex to the temporal allocortex (entorhinal region and hippocampal formation). These evolutionary trajectories are seen in reverse order by the gradual extension of the AD-related cortical tau pathology, which starts in the transentorhinal region and finally reaches the primary areas of the neocortex (Figs. 1 and 2) (Braak and Del Tredici 2015a,b).

The first cortical neurons to become involved closely resemble the multipolar neurons of the superficial entorhinal layer pre- $\alpha$ (Braak and Braak 1992). In the transentorhinal region, such cells slope gradually downward until they reach the upper surface of layer $\mathrm{V}$ and thereby undergo a gradual transformation from starshaped multipolar cells in the entorhinal layer pre- $\alpha$ into modified pyramidal cells with a gradually developing apical dendrite (Braak 1980; Braak and Braak 1992). Tau aggregates 
initially appear in distal dendritic segments of these pyramidal cells and then fill the soma and the axon (Braak et al. 1994a). Notably, the distal dendritic segments of cortical pyramidal cells are phylo- and ontogenetically late-appearing structures that chiefly receive axonal contacts of late-emerging and late-maturing projection neurons, among them the projection neurons from the nonthalamic nuclei.

It is unknown which pathological mechanisms feature in the production of large amounts of abnormal tau that eventually fill much of the cytoplasm of transentorhinal neurons with pretangles. Normally, tau proteins are present only at low concentrations in the somatodendritic compartment of nerve cells because the microtubuli in this compartment are stabilized by other proteins and do not need large amounts of tau (Braak and Del Tredici 2015). The abrupt appearance of pathological tau within the somatodendritic compartment could be caused by defective mechanisms in functionally impaired axons of involved nonthalamic nuclei (e.g., coeruleus neurons), which then send aberrant signals to the cortical nerve cells on which they synapse. These signals, in turn, might induce a transient overproduction of the protein tau in the somatodendritic compartment of the recipient neuron. Because only a small fraction of nascent tau proteins finds binding sites there, tau presumably exists in the somatodendritic compartment in a mostly hyperphosphorylated state.

Within the somatodendritic compartment, a variety of reactions is possible once a critical threshold has been reached. Either the superfluous hyperphosphorylated tau proteins are rapidly degraded and removed by existing cellular systems, or having exceeded critical levels, they convert into an irreversibly hyperphosphorylated and minimally aggregated state within a short interval (Kopeikina et al. 2012). A second option would be that the unneeded hyperphosphorylated tau requires a "seed" to initiate the aggregation process in the recipient neuron. It is possible that seeds are, above all, the still soluble but irreversibly hyperphosphorylated and slightly aggregated tau mole- cules that could be transmissible from presynaptic terminals of pathologically changed axons to the postsynaptic sites of recipient neurons. Such pathological forms of tau apparently exist for only a brief time interval, and their only chance of survival for any considerable time is within the axonal compartment of involved neurons (i.e., there where degradation mechanisms are not available). It remains possible that miniscule particles of pathogenic tau could be released into the synaptic cleft and endocytosed at the postsynaptic site by the recipient neuron. Once inside the recipient nerve cell, the tau molecules could act similarly to prions, initiating the aggregation of newly produced abnormal tau (Frost et al. 2009; Pooler et al. 2013; Holmes and Diamond 2014; Sanders et al. 2014). The conditions needed to promote or enhance prion-like formation are incompletely understood, but there is increasing experimental evidence for the concept that aggregated tau is transferred from one nerve cell to another and induces the aggregation of abnormal tau in receptor cells (Goedert et al. 2010, 2014; Lee et al. 2010; Guo and Lee 2011; Jucker and Walker 2011; Liu et al. 2012; van Ba et al. 2013; Dujardin et al. 2014; Sanders et al. 2014; Falcon et al. 2015; Jackson et al. 2016).

The most essential interconnecting pathways between the chief regions of the neocortex in general consist of upstream corticocortical projections (i.e., projections from primary areas to secondary fields, and from there, to highorder association areas that have features in common with precisely aimed thalamocortical projections) (Fig. 2, thin black arrow). These interconnections are given off from pyramidal cells of supragranular layers (layers II and III) and preferably reach layer IV of their target areas, which, in addition, also receives thalamocortical projections. The neocortical layer IV consists of small pyramidal cells (spiny stellate cells) that are specialized at receiving information effectively and distribute data radially to the remaining cell layers (Bannister 2005). Short upstream projections from the primary sensory fields reach the first-order sensory association areas (secondary areas). Supragranular pyramidal cells from the primary and 
secondary areas then send somewhat longer axons to layer IV of the adjoining high-order sensory association areas (Fig. 2) (Barbas 2007). In this manner, sensory data proceed sequentially from the primary fields through the secondary areas and into high-order association fields. From there, the data are conveyed via long corticocortical projections to layer IV of the prefrontal areas (Fig. 2, thick black arrow).

Short downstream or return pathways from the prefrontal cortex or high-order sensory association areas to secondary, and ultimately primary, fields are provided by projections that originate chiefly in infragranular layers (layers $\mathrm{V}$ and VI) and terminate, widely distributed, in layers I-III and layers V and VI of their target areas, whereas layer IV has only sparse contacts (Fig. 2, dashed arrows) (Barbas 2007). The downstream pathways project to cortical fields in a much less focused and effective manner than the upstream projections, and thus, they resemble the diffuse projections originating from the nonthalamic nuclei more closely. In the frontal neocortex, downstream pathways transmit data from prefrontal fields to premotor and primary motor areas, which ultimately relay motor programs to the lower brainstem and spinal cord (Fig. 2, dashed arrows). Because the downstream pathways lack precision, most of the dataflow is directed parallel to them into striatal and cerebellar circuits, which integrate the basal ganglia, thalamus, nuclei of the lower brainstem, and cerebellum into the regulation of cortical output (Fig. 2, thick black arrow) (Alheid 2003; Heimer and van Hoesen 2006; DeLong and Wichmann 2007).

After lesions develop in the transentorhinal region (NFT stage I), the AD-related pathological process progresses into the entorhinal region and into the hippocampal formation via the perforant path (NFT stage II). From the transentorhinal region, it encroaches on the adjoining temporal neocortex during NFT stage III and, from there, more widely into the temporal, insular, and frontal neocortex during NFT stage IV (Fig. 2). The possible propagation of the disease process from the transentorhi-
Tau and $\alpha$-Synuclein Dissemination in AD and PD

nal region to the entire neocortex is likely to take place via corticocortical projections of the downstream pathways-that is, via pyramidal cells in layers V and VI, the axons of which diffusely terminate in layers I-III and V and VI of their target areas, with very few interconnectivities in layer IV (Fig. 2, dashed arrows). At the same time, the disease process is supported by similarly diffuse projections from corresponding portions of the nonthalamic nuclei (Fig. 1), thus virtually sparing neocortical layer IV in $\mathrm{AD}$. As a result, models are needed to investigate if one of the two routes (coeruleocortical or corticocortical) is sufficient to transmit tau pathology or if both routes influence the same sites of recipient neurons (i.e., distal segments of dendrites), working together to spread the pathological process. As discussed above, the pallidum remains beyond the influence of cholinergic, serotonergic, and noradrenergic networks, and it is not reached via the corticocortical downstream pathway. Does this lack of connectivity account for why the pallidum consistently fails to develop tau pathology (and $A \beta$ ) in the course of $A D$ ? Finally, it should also be tested in an experimental model whether, after severing coeruleus axons ipsilaterally, tau pathology fails to develop in the transentorhinal region (NFT stage I) and/or in axons and neurons of the spinal cord (NFT stage III) (Fig. 2).

The hypothesis of a neuron-to-neuron seeding and anterograde propagation via synapses with pre- and postsynaptic sites offers a parsimonious explanation for both the predictable regional distribution pattern of the tau lesions and the gradual rate of disease progression in $\mathrm{AD}$ (Braak and Del Tredici 2011b, 2015a). With knowledge of the underlying mechanisms and pathogenicity of different tau strains, it might be possible to delay or interrupt the spread of the pathology (Pooler et al. 2013; Braak and Del Tredici 2015a,b). The prospect of developing a causally based therapy for $\mathrm{AD}$ during the phase when the process is still confined to the lower brainstem, and at the very least prior to the involvement of the neocortex, is highly challenging but certainly worthwhile. 


\section{SPREAD OF PATHOLOGICAL $\alpha$-SYNUCLEIN LESIONS IN PD}

As in $\mathrm{AD}$, the pathological process in sporadic $\mathrm{PD}$ progresses predictably from one region to another (Braak et al. 2003a; Braak and Del Tredici 2009; Dickson et al. 2009; Halliday et al. 2012; van de Berg et al. 2012; Goedert et al. 2013; McCann et al. 2015). A major difference between the two diseases, however, is that in $\mathrm{PD}$ the $\mathrm{OB}$ (Fig. 4) and the dorsal motor nucleus of the vagal nerve $(\mathrm{dmX})$, rather than the locus coeruleus, become involved at the earliest stage (Fig. 4, dark purple). Whereas vagal (dmX) efferences connect the CNS closely with the ENS and PNS, the projections of the locus coeruleus only reach sites within the CNS (Fig. 4). These features may account for the noticeable differences between the regional distribution patterns and progression of both pathologies: Although abnormal tau remains virtually confined to the CNS in AD (Arnold et al. 2010; Braak and Del Tredici 2015a), synucleinopathy in PD develops in all divisions of the nervous system (CNS, ENS, and PNS) (Beach et al. 2010; Del Tredici et al. 2010; Del Tredici and Braak 2012; Malek et al. 2014).

Intracerebrally, the $\mathrm{PD}$-associated process consistently begins (PD stage 1) in the $\mathrm{OB}$ (chiefly in the anterior olfactory nucleus) and/ or in the $\mathrm{dmX}$ (Fig. 4, dark purple) (Pearce et al. 1995; Hawkes et al. 1999; Del Tredici et al. 2002; Braak et al. 2003a; Bloch et al. 2006; Fujishiro et al. 2008; Beach et al. 2009; Braak and Del Tredici 2009; Markesbery et al. 2009). Spindleshaped $\alpha$-synuclein aggregates, or Lewy neurites (LNs) (Spillantini et al. 1997; Braak et al. 1994b, 1999; Duda 2006; Tofaris and Spillantini 2007), appear in dendrites of the visceromotor neurons of the $\mathrm{dmX}$. These LNs are sometimes accompanied by globular somatic inclusions, or LBs, in $\mathrm{dmX}$ visceromotor neurons and by LNs in the unmyelinated and long axons of the $\mathrm{dmX}$ projection cells in the medulla. In contrast, the motor cells in the ambiguus nucleus of the vagal nerve that innervate the striated musculature of the larynx and proximal esophagus are spared (Eadie 1963; Del Tredici et al. 2002; Braak et al. 2003a). The pathological process generally pro- gresses from the $\mathrm{dmX}$ caudorostrally through vulnerable regions of the medulla oblongata, tegmentum pontis, as well as the mid- and forebrain until it reaches the cerebral cortex (Braak et al. 2003a; Goedert et al. 2013).

In stage 2, Lewy pathology develops in nuclei of the level-setting system: the lower raphe nuclei, magnocellular portions of the reticular formation, and the locus coeruleus (Braak et al. 2003a; Braak and Del Tredici 2009). The descending projections of these superordinate nuclei regulate spinal cord and medullary centers both for somato- and viscerosensory input as well as for viscero- and somatomotor output. Moreover, this system can temporarily reduce the conduction of incoming pain signals while raising attention levels and placing the organism's motor neurons in a heightened state of readiness (Fig. 4, light purple) (Nieuwenhuys 1996; Del Tredici and Braak 2012). It is possible that descending projections from the involved supraspinal level-setting nuclei (beginning in stage 2 and continuing in stage 3 ) transfer or disseminate aggregated $\alpha$-synuclein in an anterograde direction to axons in the spinal cord, including lateral portions of layers 7 (viscerosensory/visceromotor autonomic centers, intermediolateral nucleus [IML], sacral parasympathetic nucleus [SPS]), 1 (nociception), and 9 (somatomotor system) (Fig. 4, dark and light purple) (Braak et al. 2007; Del Tredici and Braak 2012; see also Wakabayashi and Takahashi 1997b; Bloch et al. 2006; Klos et al 2006). A possible additional route, this time for retrograde transport and transsynaptic transmission of $\alpha$-synuclein, is from the periphery (ENS) via the postganglionic sympathetic projection neurons of the celiac ganglion (PNS) to the preganglionic sympathetic neurons of the intermediolateral (IML) nucleus in layer 7 of the spinal cord (Fig. 4, IML, PNS, and ENS) (Braak et al. 2006; see also Wakabayashi and Takahashi 1997a,b; Haï et al. 2004; Braak and Del Tredici 2009).

During stage 2, PD-associated lesions in the periphery (PNS) are seen in the sympathetic trunk, sympathetic peripheral prevertebral ganglia, sympathetic nerves of the submandibular gland, and selected types of projection neurons in the intramural plexus of the ENS (Fig. 4, light 

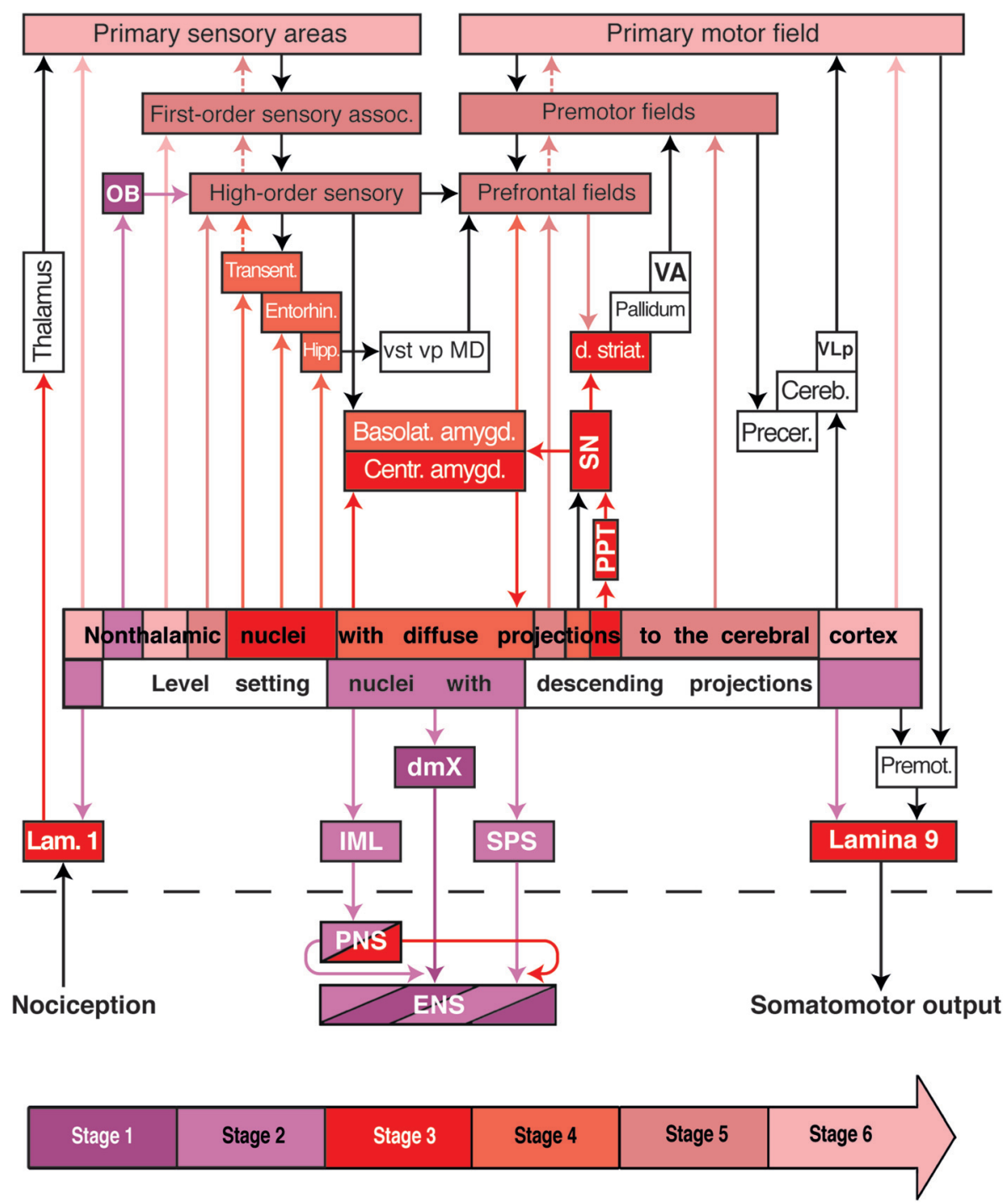

Figure 4. Possible routes of $\alpha$-synuclein transmission in Parkinson's disease (PD). The color-coded arrow at the bottom of the diagram indicates PD neuropathological stages 1-6 and PD-related lesions. Color-coded arrows (excluding black arrows) are intended to indicate the routes along which the pathology may disseminate transneuronally by anterograde or retrograde transport. A dashed black line separates the central from the peripheral and enteric nervous systems. The diagram shows the early involved level-setting nuclei with descending projections and nonthalamic nuclei with ascending projections in relationship to the pathological process. The lesions do not develop at all predilection sites within the nervous system simultaneously, but rather, sequentially. In stage 1 (dark purple), Lewy pathology is present within anterior olfactory structures (OB), in the dorsal motor nucleus of the vagus nerve $(\mathrm{dmX})$, and in the intermediate reticular zone (not shown). The ambiguus nucleus is spared. Between stages 2 and 6, the pathological process progresses caudorostrally through the neuraxis. In stage 2 (light purple), the pathology reaches the level-setting nuclei of the lower brainstem (lower raphe group, gigantocellular nucleus of the reticular formation, and locus coeruleus), followed by a group of nonthalamic nuclei that project widely to the cerebral cortex (hypothalamic tuberomamillary nucleus, Meynert's basal nucleus, the interstitial nucleus of the diagonal band, medial septal nucleus). (Legend continues on following page.) 
purple) (Bloch et al. 2006; Braak et al. 2006; Braak and Del Tredici 2009; Del Tredici et al. 2010; see also den Hartog Jager and Bethlem 1960; Wakabayashi et al. 1988, 1989, 1990, 1993; Takeda et al. 1993; Wakabayashi and Takahashi 1997a,b; Cersósimo et al. 2011; Beach et al. 2013; Adler et al. 2014). The brain is closely connected with postganglionic ENS neurons via axons of the preganglionic parasympathetic motor neurons of the $\mathrm{dmX}$. Pathologically altered LNs in the submucosal plexus develop in close proximity to the gastric glands directly beneath the epithelial lining of the stomach and esophagus (Braak et al. 2006). For this reason, we postulated earlier that an unknown pathogenic agent (e.g., an environmental toxin) or pathologically altered $\alpha$-synuclein could adhere to the mucous membranes of the nose and upper gastrointestinal tract and, akin to a neurotropic virus (Jang et al. 2009a,b), then be transmitted to superficial nerve cells and cellular processes of the submucosal plexus in the esophagus or stomach (Fig. 4, dark purple) (Braak et al. 2003b, 2006; Hawkes et al. 2007).
From there, the hypothesis was that Lewy pathology might reach the $\mathrm{dmX}$ in the lower brainstem via the myenteric plexus and retrograde axonal transport through unmyelinated axons of the peripheral vagus nerve (Braak et al. 2003b; Hawkes et al. 2007; Braak and Del Tredici 2009; see also George et al. 2013; Olanow and Brundin 2013; Holmqvist et al. 2014; Ulusoy et al. 2014).

The distal esophagus and stomach are among the more likely sites for a transfer of $\alpha$-synuclein between interconnected neurons because there the ENS underlies predominantly vagal influence (Richards and Sugarbaker 1995; Benarroch 2007; Cersósimo and Benarroch 2008). Moreover, the presence of Lewy pathology in colonic biopsies (Lebouvier et al. 2008, 2010; Pouclet et al. 2011; Shannon et al. 2012) indicates that the intramural plexus in the lower gastrointestinal tract might be an additional source of a route for retrograde dissemination of synucleinopathy to the dmX. Currently, no definitively confirmed autopsy-based evidence exists for either phenomenon (Beach et al.

Figure 4. (Continued) Involvement of midbrain nuclei (tegmental pedunculopontine nucleus [PPT], substantia nigra, pars compacta $[\mathrm{SN}]$, the upper raphe group) and the central subnucleus of the amygdala mark stage 3 (dark red). In stage 4 (dark red), additional subnuclei of the amygdala develop Lewy pathology and the cerebral cortex (transentorhinal region [transent], entorhinal region [entorhin], hippocampal formation [hipp]) become involved. During stages 5 and 6 (dark/light pink), lesions develop chiefly in projection neurons of the deep layers of the neocortex, beginning in the high-order sensory association areas and prefrontal fields. From there, the pathology advances into first-order sensory association areas and premotor fields, eventually reaching the primary sensory and motor fields. Spinal cord lesions, probably resulting from the level-setting nuclei via anterograde axonal transport, first develop at stage 2 in preganglionic sympathetic neurons of the intermediolateral nucleus (IML) and sacral parasympathetic nucleus (SPS) (light purple), followed during stage 3 by lesions in nociceptive projection neurons of layer 1 (lam. 1) and in $\alpha$-motoneurons, including those of Onuf's nucleus, in layer 9 (lamina 9) (dark red). Alternatively, the IML could be reached by the spread of pathology from sympathetic postganglionic neurons of the peripheral celiac ganglion ( peripheral nervous system [PNS]), which have contacts in the enteric nervous system (ENS). Based on known anatomical connectivities, the autonomic intramural plexus of the ENS could be either the source (dark purple, via retrograde transport) of the pathology in the $\mathrm{dmX}$ or the recipient (light purple, via anterograde transport) of the pathology from the dmX. Similarly, the lesions could disseminate to the locus coeruleus (stage 2) by retrograde transport from the olfactory bulb $(\mathrm{OB})$ and/or from the $\mathrm{dmX}$ (stage 1). First-order sensory assoc., first-order sensory association areas; basolat. amygd., amygdala, basolateral subnuclei; $\mathrm{OB}$, olfactory bulb (chiefly the anterior olfactory nucleus); high-order sensory, high-order sensory association areas; centr. amygd., central subnucleus, amygdala; cereb, cerebellum; $\mathrm{dmX}$, dorsal motor nucleus of the vagal nerve; $d$. striat, dorsal striatum; ENS, enteric nervous system (submucosal and myenteric plexus); entorhin, entorhinal region; hipp, hippocampal formation (subiculum, Ammon's horn, and dentate fascia); MD, mediodorsal nuclei of the thalamus; PNS, peripheral nervous system (e.g., sympathetic trunk, celiac and superior cervical ganglia, and submandibular gland); precer, precerebellar nuclei; VA, ventral anterior nucleus of the thalamus; VLp, posterior ventrolateral nucleus of the thalamus; vp, ventral pallidum; vst, ventral striatum. 
2010). It is, however, remarkable that in experimental models, following intragastric or intraduodenal applications, $\alpha$-synuclein propagation (i.e., a progression) from the periphery to the brain $(\mathrm{dmX})$ occurred over considerable anatomical distances (Miwa et al. 2006; Pan-Montojo et al. 2010; Holmqvist et al. 2014; cf. Sacino et al. 2014). Conversely, when vagotomy was performed, Lewy pathology dissemination from the gut to the $\mathrm{dmX}$ failed to occur or the incidence of PD was remarkably reduced (PanMontojo et al. 2012; Svensson et al. 2015).

In in vitro (Volpicelli-Daley et al. 2011; Freundt et al. 2012) and animal models (Recasens et al. 2014), misfolded $\alpha$-synuclein is capable of both retrograde and anterograde axonal transport (see also George et al. 2013). Thus, despite the lack of verifiable evidence in human autopsy cases to date and although neither the olfactory mucosa, olfactory fila, nor olfactory glomerula have been reported to develop $\alpha$-synuclein aggregates (Duda et al. 1999), both of the following additional routes of $\alpha$-synuclein propagation during stages 1 and 2 are conceivable from an anatomical standpoint: (1) $\alpha$-Synuclein could disseminate to the locus coeruleus in stage 2 by retrograde transport and transsynaptic transmission from the $\mathrm{OB}$ and anterior olfactory nucleus (stage 1) (Shipley et al. 1985; Marien et al. 2004; Doty 2008). (2) $\alpha$-Synuclein could also disseminate from the $\mathrm{dmX}$ in stage 1 by retrograde transport to the locus coeruleus and by anterograde transport to ENS nerve cells, where Lewy pathology can be observed from at least stage 2 onward (Fig. 4, light/dark purple) (Braak et al. 2006; Del Tredici et al. 2010; but see Del Tredici and Braak 2012; Stokholm et al. 2016). The pathology could consist of misfolded $\alpha$-synuclein molecules, minimally aggregated inclusions, or fragments of both, and be capable of inducing conformational changes in normal $\alpha$-synuclein within previously uninvolved recipient neurons. As in tau models of $\mathrm{AD}$, there is also some experimental evidence that $\alpha$-synuclein can be taken up into neurons by endocytosis (Desplats et al. 2009; Luk et al. 2009; Nonaka et al. 2010; Hansen et al. 2011; Volpicelli-Daley et al. 2011; George et al. 2013). Most of the misfolded $\alpha$-synuclein molecules
Tau and $\alpha$-Synuclein Dissemination in AD and PD

(presumably originating in synaptic terminals) would be transported via the axon in a retrograde direction to the soma to undergo proteosomal or other forms of degradation. However, the somatic proteinaceous inclusions probably would be too numerous and/or too large to be eliminated by cellular mechanisms, and multiple somatic LBs would develop (Braak and Del Tredici 2009; Del Tredici and Braak 2013).

In stage 2, the level-setting nuclei send strong projections to the $\mathrm{dmX}$. Their existence indicates that retrograde axonal and transneuronal transport via descending fibers could disseminate the pathology from the $\mathrm{dmX}$ to the level-setting nuclei. However, it cannot be ruled out that involvement of isolated level-setting projection neurons (e.g., in the locus coeruleus) may precede involvement of nerve cells in the $\mathrm{dmX}$ and propagate the pathological process anterogradely from the coeruleus to the $\mathrm{dmX}$. The anterograde transfer of a pathogen from the locus coeruleus not only is conceivable via connectivities with the anterior olfactory nucleus (Fig. 4) (i.e., in the absence of pathological lesions in the olfactory mucosa and olfactory glomerula) but also would explain the enigmatic finding of isolated $L N s$ that are often confined to dendrites of $\mathrm{dmX}$ visceromotor neurons at stage 1 (Fig. 3) (Braak and Del Tredici 2009). As discussed above, spinal cord involvement, which begins in portions of layer 7 during stage 2 (Fig. 4, light purple), likely occurs via anterograde transport because anatomical connectivities make it possible that the lesions developing there originate from descending projections in the supraspinal level-setting nuclei.

During stage 3 , additional groups of nerve cells in the spinal cord that are the targets of level-setting nuclei projections develop Lewy pathology. These include the large nociceptive projection neurons in layer 1 and the $\alpha$-motoneurons in layer 9 , including the motoneurons of Onuf's nucleus (Fig. 4, dark red) (Del Tredici and Braak 2012). The caudorostral trajectory of the Lewy pathology makes inroads at this stage into the mesencephalic tegmentum and basal portions of the prosencephalon (Fig. 4, dark red). Neuronal loss occurs not only in components of the somatomotor system (e.g., the teg- 
mental pedunculopontine nucleus [PPT] and pars compacta of the substantia nigra $[\mathrm{SN}]$ ) but also in the nuclei of the upper raphe system, the central subnucleus of the amygdala (Fig. 4, dark red), the hypothalamic tuberomamillary nucleus, and the magnocellular nuclei of the basal forebrain (medial septal nucleus, interstitial nucleus of the diagonal band, and basal nucleus of Meynert) (Braak et al. 2003a; Braak and Del Tredici 2009).

Within the limbic system, the central subnucleus of the amygdala (Braak et al. 1984) is densely and bidirectionally connected with level-setting nuclei and the $\mathrm{dmX}$, thereby providing supervening limbic input to these supraspinal nuclei (Fig. 4) (Sims and Williams 1990; Liubashina et al. 2000). Newer studies are required to determine whether pathways possibly disseminate the $\alpha$-synuclein pathology via retrograde or anterograde transport to the central subnucleus and by means of which pathways the pathological process reaches the dopaminergic neurons of the SN. Among these, however, are probably the tegmental pedunculopontine nucleus (anterograde transport via direct projections) and/or coeruleonigral projections (Fig. 4, dark red) (Collingridge et al. 1979; Jones and Yang 1985).

In stage 4 , the pathological process penetrates the forebrain and enters a specific portion of the cerebral cortex for the first time: the transentorhinal region in the anteromedial temporal lobe (Fig. 4, light red). As pointed out above for $\mathrm{AD}$, this unique architectonic entity functions as a transitional zone between the allo- and neocortex. It is highly developed only among higher primates and, above all, in humans (Braak and Braak 1992; Braak and Del Tredici 2015a). In subsequent stages, the transentorhinal region develops the most severe Lewy pathology within the cerebral cortex (Braak and Del Tredici 2009). Moreover, it is remarkable that the PD-related pathological process develops only in the presence of an $\mathrm{AD}$-related process that has reached at least stages $1 \mathrm{a}, 1 \mathrm{~b}$, or higher (Marien et al. 2004; Braak and Del Tredici 2015a; see also Arai et al. 2001; Ishizawa et al. 2003; Fujishiro et al. 2008). Whether a "synergism" exists between the two pathological proteins, and if so, which one takes the lead, is currently unknown. We believe it may be tau because tau pathology precedes the synucleinopathy (Fig. 3E,F) (Braak and Del Tredici 2011a, 2015a).

The locus coeruleus, together with the basolateral nuclei of the amygdala and magnocellular nuclei of the basal forebrain, is bidirectionally connected with the anteromedial temporal cortex and transentorhinal region. Dissemination along these connectivities might well enable the synucleinopathy (in stage 4) to reach the transentorhinal region by means of anterograde axonal and transneuronal transport. As if through the eye of a needle, all significantly memorable data arriving from the neocortical sensory association areas must transit through the transentorhinal/entorhinal regions and the perforant path to reach the hippocampal formation (Fig. 4, dark red). Via this route, the pathological process could be propagated to the cortical predilection sites in anteromedial portions of the temporal lobe.

The topographic extent of the PD-related process is greatest during end-stages 5 and 6. With the transentorhinal region as its cortical beachhead, the synucleinopathy gradually spreads throughout the entire neocortex (Fig. 4, dark pink). At stage 5, Lewy pathology develops in high-order sensory association areas and prefrontal fields of the neocortex (e.g., insular, subgenual, and anterior cingulate areas, i.e., organizational areas for processing interoceptive data and regulating visceromotor and endocrine functions). In stage 6 , the pathological process spreads to the first-order sensory association areas, premotor fields, and even into the primary sensory and motor fields (Fig. 4, light pink) (Braak et al. 2003a; Braak and Del Tredici 2009). Like falling dominos, successive neocortical regions display beginning, followed by increasing, degrees of synucleinopathy (Fig. 5). The relatively small neocortical pyramidal cells that contain $\alpha$-synuclein aggregates occur chiefly in layers V and VI (Wakabayashi et al. 1995). This pattern of progression conforms well with the concept that propagation of the disease process throughout the neocortex likely takes place via corticocortical projections 
of the downstream pathways, similar to the situation proposed here for AD. Downstream projections have numerous diffuse synaptic contacts in layers I-III and also V and VI but very few in layer IV. As in AD, neocortical layer IV is virtually spared in PD, and most of the Lewy pathology develops in layers V and VI. At the same time, the cortical disease process (anterograde transmission via corticocortical pathways) could be supported, as in $\mathrm{AD}$, by projections from the locus coeruleus (coeruleocortical projections) and other widely projecting non-
A

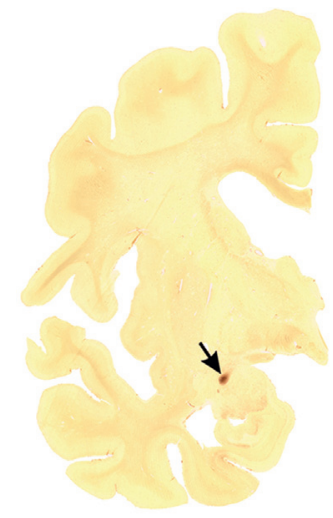

PD stage 3

C

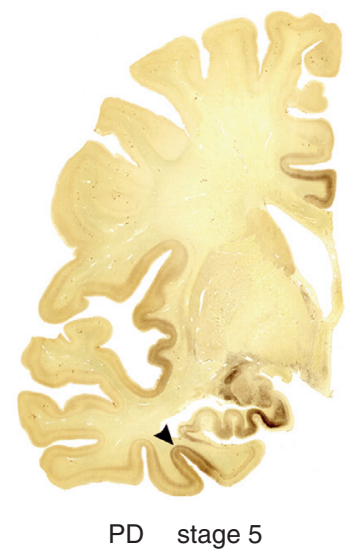

B

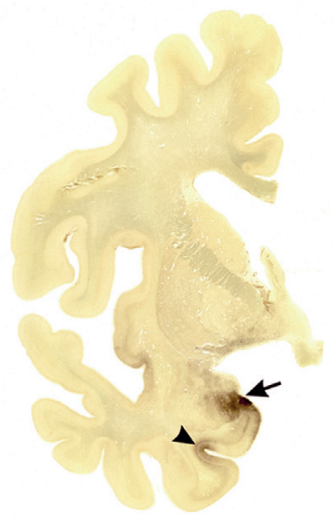

PD stage 4

D

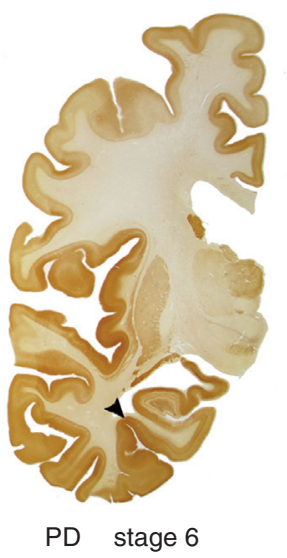

Figure 5. Lewy pathology in $100 \mu \mathrm{m}$ polyethylene glycol-embedded hemisphere sections at stages 3-6 of sporadic Parkinson's disease (PD). (A) The arrow indicates the presence of the lesions in the central subnucleus of the amygdala. The cerebral cortex is still uninvolved at stage 3. (B) During stage 4, additional subnuclei of the amygdala develop Lewy pathology (the arrow points to cortical and basolateral subnuclei). Initial cortical lesions begin to appear at this stage in a specific portion of the anteromedial temporal lobe: the transentorhinal region (arrowhead). This region is a transitional zone wedged between allo- and neocortical regions and is especially developed only among higher primates, above all, in humans. $(C)$ The pathological process progresses in stage 5 (moving clockwise from the transentorhinal region) into regions of the neocortex. Here, in addition to the increasing pathology present in the transentorhinal region (arrowhead), the inclusions in limbic portions of the temporal, insular, and cingulate cortex, in the hippocampal formation, and in the subnuclei of the amygdala gradually worsen. $(D)$ During stage 6 , the destruction in the temporal, insular, and cingulate regions is very severe. Not only the first-order sensory association areas and premotor fields of the neocortex, but also the neocortical primary sensory (including the primary auditory gyrus of Heschl) and motor fields become heavily involved. The arrowhead points to the transentorhinal region. $(A-D) \alpha$-Synuclein immunohistochemistry. 
thalamic nuclei that become involved early in the process.

\section{CONCLUDING REMARKS}

In $\mathrm{AD}$ and $\mathrm{PD}$, only projection cells with a disproportionately long and unmyelinated or sparsely myelinated axon develop proteinaceous aggregates, whereas interneurons and projection cells with comparatively short axons generally do not. In fact, only a few nerve cell types within the human nervous system are able to develop tau or $\alpha$-synuclein pathology, whereas contiguous neurons or those near involved regions remain intact (Braak and Del Tredici 2009, 2015a). This can complicate the assessment of the results achieved in cellular and animal models, which, in contrast to human pathology, sometimes display nonsynaptic or nonselective (i.e., contiguous) rather than selective spreading along axonal connectivities (Freundt et al. 2012; Kaufman and Diamond 2013; cf. Ahmed et al. 2014). In addition, the pathogenicity and potential intrinsic noxious gain-of-function mechanisms for hyperphosphorylated tau and Lewy pathology are still controversial (Cookson 2006; Quilty et al. 2006; Dickson et al. 2009; Kopeikina et al. 2012; Malek et al. 2014).

The potential prion-like properties associated with abnormal tau and $\alpha$-synuclein indicate that both are not neuroprotective. In addition, within the context of proteinopathies, in which the degradation and removal of abnormal proteins malfunction, both are linked with considerable certainty to the pathogenic process, because the breakdown of cellular mechanisms for degrading and clearing abnormal tau and $\alpha$-synuclein make them ultimately deleterious to neuronal equilibrium (Chung et al. 2001; Ciechanover 2005; Olanow and McNaught 2006; Rubinsztein 2006; Lim and Tan 2007; Upadhya and Hegde 2007a,b; Pan et al. 2008; Lehman 2009; Kovacech et al. 2010; Ebrahimi-Fakhari et al. 2012; Kopeikina et al. 2012; Tai et al. 2012). There is also evidence that intra-axonal $\alpha$-synuclein and intraneuronal tau aggregates are associated with axonopathy (Irizarry et al. 1998; Saha et al. 2004;
Duda et al. 2006; Stokin and Goldstein 2006; Orimo et al. 2008; Kanazawa et al. 2011; Lingor et al. 2012; Lamberts et al. 2015), cell membrane dysfunction (Tsigelny et al. 2012), or cellular dysfunction (Dugger and Dickson 2010). Depending on study design, some experimental models display motor impairment, cognitive impairment, or deficits in neuronal excitability and/or cell loss (Giasson et al. 2002; Sydow et al. 2011; Volpicelli-Daley et al. 2011; Luk et al. 2012a; Sacino et al. 2014; Brelstaff et al. 2015; Ozcelik et al. 2016).

In $\mathrm{AD}$, tau pathology develops prior to $\mathrm{A} \beta$ deposition (Braak and Del Tredici 2011a, 2014, 2015a,b; Braak et al. 2011) and possibly impairs axoplasmic flow and axonal transport (Utton et al. 2002; Iqbal et al. 2009); in PD, LNs occur at most sites prior to LBs, probably disrupting somatopetal and/or somatofugal transport and interfering with normal cellular functioning (Duda et al. 2006; Del Tredici and Braak 2013; Volpicelli-Daley et al. 2014). Although many neurons containing neurofibrillary lesions or multiple LBs and LNs survive for decades, this does not imply that mere survival can be equated with functional integrity (Braak and Del Tredici 2009, 2015a). Premature neuronal loss is the endpoint of the pathological process, but increasingly compromised cellular function in large numbers of neurons almost certainly drives the degeneration that contributes to premature cell death in AD and PD.

\section{ACKNOWLEDGMENTS}

This work is supported in part by the German Research Council (Deutsche Forschungsgemeinschaft [DFG] Grant TR 1000/1-1), the 2014 Robert A. Pritzker Prize from the Michael J. Fox Foundation for Parkinson's Disease Research, and the 2015 Annemarie Opprecht Prize (Bern, Switzerland). The authors thank Mr. David Ewert (University of Ulm) for technical assistance with the illustrations.

\section{REFERENCES}

Adler CH, Dugger BN, Hinni ML, Lott DG, Driver-Dunckley E, Hidalgo J, Henry-Watson J, Serrano G, Sue LI, 
Tau and $\alpha$-Synuclein Dissemination in AD and PD

Nagel T, et al. 2014. Submandibular gland needle biopsy for the diagnosis of Parkinson disease. Neurology 82: $858-864$.

Agnati LF, Bjekle B, Fuxe K. 1995. Volume versus wiring transmission in the brain: A new theoretical frame of neuropsychopharmacology. Med Res Rev 15: 33-45.

Aguzzi A. 2009. Beyond the prion principle. Nature 459: 924-925.

Aguzzi A, Calella AM. 2009. Prions: Protein aggregation and infectious diseases. Physiol Rev 89: 1105-1152.

Aguzzi A, Rajendran L. 2009. The transcellular spread of cytosolic amyloids, prions, and prionoids. Neuron 64: 783-790.

Ahmed Z, Cooper J, Murray TK, Gara K, McNaughton E, Clarke H, Parhizkar S, Ward MA, Cavallini A, Jackson S, et al. 2014. A novel in vivo model of tau propagation with rapid and progressive neurofibrillary tangle pathology: The pattern of spread is determined by connectivity, not proximity. Acta Neuropathol 127: 667-683.

Alafuzoff I, Thal DR, Arzberger T, Bodganovic N, Al-Sarraj S, Bodi I, Boluda S, Bugiani O, Buckaerts C, Gelpi E, et al. 2009. Assessment of $\beta$-amyloid deposits in human brain: A study of the BrainNet Europe Consortium. Acta Neuropathol 117: 309-320.

Alheid GF. 2003. Extended amygdala and basal forebrain. Ann NY Acad Sci 985: 185-205.

Angot E, Steiner JA, Hansen C, Li JY, Brundin P. 2010. Are synucleinopathies prion-like disorders? Lancet Neurol 9: $1128-1138$.

Angot E, Steiner JA, Lema Tomé CM, Ekström P, Mattsson B, Björkland B, Brundin P. 2012. $\alpha$-Synuclein cell-to-cell transfer and seeding in grafted dopaminergic neurons in vivo. PLoS ONE 7: e39465.

Arai Y, Yamazaki M, Mori O, Muramatsu H, Asano G, Katayama Y. 2001. $\alpha$-Synuclein-positive structures in cases with sporadic Alzheimer's disease: Morphology and its relationship to tau aggregation. Brain Res 888: 287-296.

Arnold SE, Lee EB, Moberg PF, Stutzbach L, Kazi H, Han LY, Lee VM, Trojanowski JQ. 2010. Olfactory epithelium and amyloid- $\beta$ and paired helical filament-tau pathology in Alzheimer's disease. Ann Neurol 67: 462-469.

Aston-Jones G, Cohen JD. 2005. Adaptive gain and the role of the locus coeruleus-norepinephrine system in optimal performance. J Comp Neurol 493: 99-110.

Attems J, Jellinger KA. 2006. Olfactory tau pathology in Alzheimer's disease and mild cognitive impairment. Clin Neuropathol 25: 265-271.

Bannister AP. 2005. Inter- and intra-laminar connections of pyramidal cells in the neocortex. Neurosci Res 53: 95103.

Barbas H. 2007. Specialized elements of orbitofrontal cortex in primates. Ann NYAcad Sci 1121: 10-32.

Beach TG, White CK III, Hladik CL, Sabbagh MN, Connor DJ, Shill HA, Sue LI, Sasse J, Bachalakuri J, Henry-Watson J, et al. 2009. Olfactory bulb $\alpha$-synucleinopathy has high specificity and sensitivity for Lewy body disorders. Acta Neuropathol 117: 169-174.

Beach TG, Adler CH, Sue LI, Vedders L, Lue L, White Iii CL, Akiyama H, Caviness JN, Shill HA, Sabbagh MN, et al. 2010. Multi-organ distribution of phosphorylated $\alpha$-syn- uclein histopathology in subjects with Lewy body disorders. Acta Neuropathol 119: 689-702.

Beach TG, Adler CH, Dugger BN, Serrano G, Hildalgo J, Henry-Watson I, Shill HA, Sue LI, Sabbagh MN, Akivama H, et al. 2013. Submandibular gland biopsy for the diagnosis of Parkinson disease. J Neuropathol Exp Neurol 72: 130-136.

Beekes M, Thomzig A, Schulz-Schaeffer WJ, Burger R. 2014. Is there a risk of prion-like disease transmission by $\mathrm{Alz}$ heimer or Parkinson-associated protein particles? Acta Neuropathol 128: 463-476.

Benarroch EE. 2007. Enteric nervous system: Functional organization and neurologic implications. Neurology 69: $1953-1957$.

Benarroch EE. 2009. The locus ceruleus norepinephrine system: Functional organization and potential clinical significance. Neurology 73: 1699-1704.

Bernis ME, Babila JT, Breid S, Wüsten KA, Wüllner U, Tamgüney G. 2015. Prion-like propagation of human brain-derived $\alpha$-synuclein in transgenic mice expressing wild-type $\alpha$-synuclein. Acta Neuropathol Comm 3: 75.

Bloch A, Probst A, Bissig H, Adams H, Tolnay M. 2006. $\alpha$ Synuclein pathology of the spinal and peripheral autonomic nervous system in neurologically unimpaired elderly subjects. Neuropathol Appl Neurobiol 12: 284-295.

Bousset L, Pieri L, Ruiz-Arlandis G, Gath J, Jensen PH, Habenstein B, Madiona K, Olieric V, Böckmann A, Meier $\mathrm{BH}$, et al. 2013. Structural and functional characterization of two $\alpha$-synuclein strains. Nat Comm 4: 2575.

Braak H. 1980. Architectonics of the human telencephalic cortex, pp. 1-147. Springer, Berlin.

Braak H, Braak E. 1992. The human entorhinal cortex: Normal morphology and lamina-specific pathology in various diseases. Neurosci Res 15: 6-31.

Braak H, Del Tredici K. 2009. Neuroanatomy and pathology of sporadic Parkinson's disease. Adv Anat Embryol Cell Biol 201: 1-119.

Braak H, Del Tredici K. 2011a. The pathological process underlying Alzheimer's disease in individuals under thirty. Acta Neuropathol 121: 171-181.

Braak H, Del Tredici K. 2011b. Alzheimer's pathogenesis: Is there neuron-to-neuron propagation? Acta Neuropathol 121: 589-595.

Braak H, Del Tredici K. 2013. Evolutional aspects of Alzheimer's disease pathogenesis. JAlzheimers Dis 33: S155S161.

Braak H, Del Tredici K. 2014. Are cases with tau pathology in the absence of $\mathrm{A} \beta$ deposits part of the $\mathrm{AD}$-related pathological process? Acta Neuropathol 128: 767-772.

Braak H, Del Tredici K. 2015a. Neuroanatomy and pathology of sporadic Alzheimer's disease. Adv Anat Embryol Cell Biol 215: 1-162.

Braak H, Del Tredici K. 2015b. The preclinical phase of the pathological process underlying sporadic Alzheimer's disease. Brain 138: 2814-2833.

Braak E, Braak H, Mandelkow EM. 1994a. A sequence of cytoskeleton changes related to the formation of neurofibrillary tangles and neuropil threads. Acta Neuropathol 87: 554-567. 
Braak H, Braak E, Yilmazer D, de Vos RA, Jansen EN, Bohl J, Jellinger K. 1994b. Amygdala pathology in Parkinson's disease. Acta Neuropathol 88: 493-500.

Braak H, Sandmann-Keil D, Gai WP, Braak E. 1999. Extensive axonal Lewy neurites in Parkinson's disease: A novel pathological feature revealed by $\alpha$-synuclein. Neurosci Lett 265: 67-69.

Braak H, Del Tredici K, Rüb U, de Vos RA, Jansen Steur EN, Braak E. 2003a. Staging of brain pathology related to sporadic Parkinson's disease. Neurobiol Aging 24: 197211.

Braak H, Rüb U, Gai WP, Del Tredici K. 2003b. Idiopathic Parkinson's disease: Possible routes by which vulnerable neuronal types may be subject to neuroinvasion by an unknown pathogen. J Neural Transm 110: 517-536.

Braak H, de Vos RAI, Bohl J, Del Tredici K. 2006. Gastric $\alpha$ synuclein immunoreactive inclusions in Meissner's and Auerbach's plexuses in cases staged for Parkinson's disease-related brain pathology. Neurosci Lett 396: 67-72.

Braak H, Sastre M, Bohl JR, de Vos RA, Del Tredici K. 2007. Parkinson's disease: Lesions in dorsal horn layer I, involvement of parasympathetic and sympathetic pre- and postganglionic neurons. Acta Neuropathol 113: 421-429.

Braak H, Thal DR, Ghebremedhin E, Del Tredici K. 2011. Stages of the pathologic process in Alzheimer disease: Age categories from 1 to 100 years. J Neuropathol Exp Neurol 70: $960-969$.

Brandel JP, Corbillé AG, Derkinderen P, Haïk S. 2015. [Is Parkinson's disease a prion disease?] Rev Neurol (Paris) 171: $812-824$

Brelstaff J, Ossola B, Neher JJ, Klingstedt T, Nilsson KPR, Goedert M, Spillantini MG, Tolkovsy AM. 2015. The fluorescent pentameric oligothiophene pFTAA identifies filamentous tau in live neurons cultured from adult P301S tau mice. Front Neurosci 9: 184.

Brundin P, Li JY, Holton JL, Lindvall O, Revesz T. 2008. Research in motion: The enigma of Parkinson's disease pathology spread. Nat Rev Neurosci 9: 741-745.

Brundin P, Melki R, Kopito R. 2010. Prion-like transmission of protein aggregates in neurodegenerative diseases. Nat Rev Mol Cell Biol 11: 301-307.

Calafate S, Buist A, Miskiewicz K, Vijayan V, Daneels G, de Stropper B, de Wit J, Verstreken P, Moechars D. 2015. Synaptic contacts enhance cell-to-cell tau pathology propagation. Cell Rep 11: 1176-1183.

Cersósimo MG, Benarroch EE. 2008. Neural control of the gastrointestinal tract: Implications for Parkinson disease. Mov Disord 23: 1065-1075.

Cersósimo MG, Perandonas C, Micheli FE, Raina GB, Beron AM, Nasswetter G, Radrizzani M, Benarroch EE. 2011. $\alpha$-Synuclein immunoreactivity in minor salivary gland biopsies of Parkinson's disease patients. Mov Disord 26: $188-190$.

Ciechanover A. 2005. Proteolysis: From the lysome to ubiquitin and the proteasome. Nat Rev Moll Cell Biol 6: 79-87.

Chung KK, Dawson VL, Dawson TM. 2001. The role of the ubiquitin-proteasomal pathway in Parkinson's disease and other neurodegenerative disorders. Trends Neurosci 24: 7-14.
Clavaguera F, Bolmont T, Crowther RA, Abramowski D, Frank S, Probst A, Fraser G, Stalder AK, Beibel M, Staufenbiel M, et al. 2009. Transmission and spreading of tauopathy in transgenic mouse brain. Nat Cell Biol 11: 909-913.

Clavaguera F, Akatsu H, Fraser G, Crowther RA, Frank S, Hench J, Probst A, Winkler DT, Reichwald J, Staufenbiel M, et al. 2013a. Brain homogenates from human tauopathies induce tau inclusions in mouse brain. Proc Natl Acad Sci 110: 9535-9540.

Clavaguera F, Lavenir I, Falcon B, Frank S, Goedert M, Tolnay M. 2013b. "Prion-like" template misfolding in tauopathies. Brain Pathol 23: 342-349.

Collingridge GL, James TA, MacLeod NK. 1979. Neurochemical and electrophysiological evidence for a projection from the locus coeruleus to the substantia nigra. J Physiol 290: 44

Cookson MR. 2006. Hero versus antihero: The multiple roles of $\alpha$-synuclein in neurodegeneration. Exp Neurol 199: $238-242$.

Counts SE, Mufson EJ. 2012. Locus coeruleus. In The human nervous system, 3rd ed. (ed. Mai JK, Paxinos G), pp. 425 438. Academic, New York.

Dale GE, Probst A, Luthert P, Martin J, Anderton BH, Leigh PN. 1992. Relationships between Lewy bodies and pale bodies in Parkinson's disease. Acta Neuropathol 83: 525 529.

DeLong MR, Wichmann T. 2007. Circuits and circuit disorders of the basal ganglia. Arch Neurol 64: 20-24.

Del Tredici K, Braak H. 2012. Spinal cord lesions in sporadic Parkinson's disease. Acta Neuropathol 124: 643-664.

Del Tredici K, Braak H. 2013. Dysfunction of the locus coeruleus-norepinephrine system and related circuitry in Parkinson's disease-related dementia. J Neurol Neurosurg Psychiatry 84: 774-783.

Del Tredici K, Rüb U, de Vos RAI, Bohl JRE, Braak H. 2002. Where does Parkinson disease pathology begin in the brain? J Neuropathol Exp Neurol 61: 413-426.

Del Tredici K, Hawkes CH, Ghebremedhin E, Braak H. 2010. Lewy pathology in the submandibular gland of individuals with incidental Lewy body disease and sporadic Parkinson's disease. Acta Neuropathol 119: 703-713.

den Hartog Jager WA, Bethlem J. 1960. The distribution of Lewy bodies in the central and autonomic nervous systems in idiopathic paralysis agitans. J Neurol Neurosurg Psychiatry 23: 283-290.

Desplats P, Lee HJ, Bae EJ, Patrick C, Rockenstein E, Crews L, Spencer B, Masliah E, Lee SJ. 2009. Inclusion formation and neuronal cell death through neuron-to-neuron transmission of $\alpha$-synuclein. Proc Natl Acad Sci 106: 13010-13015.

Dickson DW, Braak H, Duda JE, Duyckaerts C, Gasser T, Halliday GM, Hardy J, Leverenz JB, Del Tredici K, Wszolek ZK, et al. 2009. Neuropathological assessment of Parkinson disease: Refining the diagnostic criteria. Lancet Neurol 8: 1150-1157.

Doty RL. 2008. The olfactory vector hypothesis of neurodegenerative diseases: Is it viable? Ann Neurol 63: 7-15.

Duda JE, Shah U, Arnold SE, Lee VM, Trojanowski JQ. 1999. The expression of $\alpha$-, $\beta$-, and $\gamma$-synucleins in olfactory mucosa. Exp Neurol 160: 515-522. 
Tau and $\alpha$-Synuclein Dissemination in AD and PD

Duda JE, Giasson BI, Lee VM, Trojanowski JQ. 2006. Is the initial insult in Parkinson's disease and dementia with Lewy bodies a neuritic dystrophy? Ann NY Acad Sci 991: 295-297.

Dugger BN, Dickson DW. 2010. Cell type specific sequestration of choline acetyltransferase and tyrosine hydroxylase within Lewy bodies. Acta Neuropathol 120: 633-639.

Dujardin S, Lécolle K, Caillierez R, Bégard S, Zommer N, Lachaud C, Carrier S, Dufour N, Aurégan G, Winderickx J, et al. 2014. Neuron-to-neuron wild-type tau protein transfer through a trans-synaptic mechanism: Relevance to sporadic tauopathies. Acta Neuropathol Commun 2: 14.

Dunning CJ, Reyes JF, Steiner JA, Brundin P. 2011. Can Parkinson's disease pathology be propagated from one neuron to another? Progr Neurobiol 97: 205-219.

Duyckaerts C. 2013. Neurodegenerative lesions: Seeding and spreading. Rev Neurol 169: 825-833.

Duyckaerts C, Uchihara T, Seilhean D, He Y, Hauw JJ. 1997. Dissociation of Alzheimer type pathology in a disconnected piece of cortex. Acta Neuropathol 93: 501-507.

Eadie MJ. 1963. The pathology of certain medullary nuclei in Parkinsonism. Brain 86: 781-792.

Ebrahimi-Fakhari D, Wahlster L, McLean PJ. 2012. Protein degradation pathways in Parkinson's disease: Curse or blessing? Acta Neuropathol 124: 153-172.

Eisenberg D, Jucker M. 2012. The amyloid state of proteins in human diseases. Cell 148: 1188-1203.

Falcon B, Cavallini A, Angers R, Glover S, Murray TK, Barnham L, Jackson S, O'Neill MJ, Isaacs AM, Hutton ML, et al. 2015. Conformation determines the seeding potencies of native and recombinant tau aggregates. J Biol Chem 290: 1049-1065.

Fiala JC. 2007. Mechanisms of amyloid plaque pathogenesis. Acta Neuropathol 114: 551-571.

Freundt EC, Maynard N, Clancy EK, Roy S, Bousset L, Sourigues Y, Covert M, Melki R, Kirkegaard K, Brahic M. 2012. Neuron-to-neuron transmission of $\alpha$-synuclein fibrils through axonal transport. Ann Neurol 72: 517524.

Frost B, Diamond MI. 2010. Prion-like mechanisms in neurodegenerative disease. Nat Rev Neurosci 11: 155-159.

Frost B, Jacks RL, Diamond MI. 2009. Propagation of tau misfolding from the outside to the inside of a cell. J Biol Chem 284: 12845-12852.

Fujishiro J, Tsuboi Y, Lin WL, Uchikado H, Dickson DW. 2008. Co-localization of tau and $\alpha$-synuclein in the olfactory bulb in Alzheimer's disease with amygdale Lewy bodies. Acta Neuropathol 116: 17-24.

Fuxe K, Borroto-Escuela DO, Romero-Fernandez W, DiazCabiale Z, Rivera A, Ferraro L, Tanganelli S, Tarakanov AO, Garriga P, Narváez JA, et al. 2012. Extrasynaptic neurotransmission in the modulation of brain function. Focus on striatal neuronal-glial networks. Front Physiol 3: 136.

George S, Rey NL, Reichenbach N, Steiner JA, Brundin P. 2013. $\alpha$-Synuclein: The long distance runner. Brain Pathol 23: 350-357.

German DC, Manaye KF, White CL 3rd, Woodward DJ, McIntire DD, Smith WK, Kalaria RN, Mann DM. 1992. Disease-specific patterns of locus coeruleus cell loss. Ann Neurol 32: 667-676.
Giasson BI, Duda JE, Quinn SM, Zhang B, Trojanowski JQ, Lee VM. 2002. Neuronal $\alpha$-synucleinopathy with severe movement disorder in mice expressing A53T human $\alpha$ synuclein. Neuron 34: 521-533.

Gibb WR, Scott T, Lees AJ. 1991. Neuronal inclusions of Parkinson's disease. Mov Disord 6: 2-11.

Goedert M. 2015. Alzheimer's and Parkinson's diseases: The prion concept in relation to assembled $A \beta$, tau, and $\alpha$ synuclein. Science 349: 1255555.

Goedert M, Spillantini MG, Davies SW. 1998. Filamentous nerve cell inclusions in neurodegenerative diseases. Curr Opin Neurobiol 8: 619-632.

Goedert M, Klug A, Crowther RA. 2006. Tau protein, the paired helical filament and Alzheimer's disease. $J$ Alzheimers Dis 9: 195-207.

Goedert M, Clavaguera F, Tolnay M. 2010. The propagation of prion-like protein inclusions in neurodegenerative diseases. Trends Neurosci 33: 317-325.

Goedert M, Spillantini MG, Del Tredici K, Braak H. 2013. 100 years of Lewy pathology. Nat Rev Neurol 9: 13-24.

Goedert M, Falcon B, Clavaguera F, Tolnay M. 2014. Prionlike mechanisms in the pathogenesis of tauopathies and synucleinopathies. Curr Neurol Neurosci Rep 14: 495.

Grundke-Iqbal I, Iqbal K, Tung YC, Quinlan M, Wisniewski HM, Binder LI. 1986. Abnormal phosphorylation of the microtubule-associated protein $\tau$ (tau) in Alzheimer cytoskeletal pathology. Proc Nat Acad Sci 83: 4913-4917.

Guest WC, Silverman JM, Pokrishevsky E, O’Neill MA, Grad LI, Cashman NR. 2011. Generalization of the prion hypothesis to other neurodegenerative diseases: An imperfect fit? J Toxicol Environ Health A 74: 1433-1459.

Guo JL, Lee VM. 2011. Seeding of normal tau by pathological tau conformers drives pathogenesis of Alzheimer-like tangles. J Biol Chem 286: 15317-15331.

Guo JL, Lee VM. 2014. Cell-to-cell transmission of pathogenic proteins in neurodegenerative diseases. Nat Med 20: $130-138$.

Haass C, Kaether C, Thinakaran G, Sisodia S. 2012. Trafficking and proteolytic processing of APP. Cold Spring Harb Perspect Med 2: a006270.

Haïk S, Faucheux BA, Hauw JJ. 2004. Brain targeting through the autonomous nervous system: Lessons from prion diseases. Trends Mol Med 10: 109-112.

Halliday G, McCann H, Shepherd C. 2012. Evaluation of the Braak hypothesis: How far can it explain the pathogenesis of Parkinson's disease? Exp Rev Neurother 12: 673-686.

Hansen C, Li JY. 2012. Beyond $\alpha$-synuclein transfer: Pathology propagation in Parkinson's disease. Trends Mol Med 18: $248-255$.

Hansen C, Angot E, Bergström AL, Steiner JA, Pieri L, Paul G, Outeiro TF, Melki R, Kallunki P, Fog K, et al. 2011. $\alpha$ Synuclein propagates from mouse brain to grafted dopaminergic neurons and seeds aggregation in cultured human cells. J Clin Invest 121: 715-725.

Hawkes CH, Shephard BC, Daniel SE. 1999. Is Parkinson's disease a primary olfactory disorder? QJM 92: 473-480.

Hawkes CH, Del Tredici K, Braak H. 2007. Parkinson's disease: A dual hit hypothesis. Neuropathol Appl Neurobiol 33: $599-614$. 
Heimer L, van Hoesen GW. 2006. The limbic lobe and its output channels: Implications for emotional functions and adaptive behavior. Neurosci Biobehav Rev 30: 126147.

Herva ME, Spillantini MG. Parkinson's disease as a member of prion-like disorders. 2015. Virus Res 2017: 38-46.

Holmes BB, Diamond MI. 2012. Cellular mechanisms of protein aggregate propagation. Curr Opin Neurol 25: $721-726$.

Holmes BB, Diamond MI. 2014. Prion-like properties of tau protein: The importance of extracellular tau as a therapeutic target. J Biol Chem 289: 19855-19861.

Holmes BB, Furman JL, Mahan TE, Yamasaki TR, Mirbaha H, Eades WC, Belaygorod L, Cairns NJ, Holtzman DM, Diamond MI. 2014. Proteopathic tau seeding predicts tauopathy in vivo. Proc Natl Acad Sci 111: E4376-E4385.

Holmqvist S, Chutna O, Bousset L, Aldrin-Kirk P, Li W, Björkland T, Wang ZY, Roybon L, Melki R, Li JY. 2014. Direct evidence of Parkinson pathology spread from the gastrointestinal tract to the brain in rats. Acta Neuropathol 128: $805-820$

Iba M, Guo JL, McBride JD, Zhang B, Trojanowski JQ, Lee VM. 2013. Synthetic tau fibrils mediate transmission of neurofibrillary tangles in a transgenic mouse model of Alzheimer's-like tauopathy. J Neurosci 33: 1024-1037.

Ikeda K, Ikeda S, Yoshimura T, Kato H, Namba M. 1978. Idiopathic Parkinsonism with Lewy-type inclusions in cerebral cortex. A case report. Acta Neuropathol 41: $165-168$.

Iqbal K, Liu F, Gong CX, Alonso Adel C, Grundke-Iqbal I. 2009. Mechanisms of tau-induced neurodegeneration. Acta Neuropathol 118: 53-69.

Irizarry MC, Growdon W, Gómez-Isla T, Newell K, George JM, Clayton DF, Hyman BT. 1998. Nigral and cortical Lewy bodies and dystrophicnigral neurites in Parkinson's disease and cortical Lewy body disease contain $\alpha$-synuclein immunoreactivity. J Neuropathol Exp Neurol 15: $112-116$.

Irwin DJ, Abrams JY, Schonberger LB, Leschek EW, Mills JL, Trojanowski JQ, Lee VM. 2013. Evaluation of potential infectivity of Alzheimer and Parkinson disease proteins in recipients of cadaver-derived human growth hormone. JAMA Neurol 70: 462-468.

Ishizawa T, Mattila P, Davies P, Wang D, Dickson DW. 2003. Colocalization of tau and $\alpha$-synuclein epitopes in Lewy bodies. J Neuropathol Exp Neurol 62: 389-397.

Jackson SJ, Kerridge C, Cooper J, Cavallini A, Falcon B, Cella CV, Landi A, Szekeres PG, Murray TK, Ahmed Z, et al. 2016. Short fibrils constitute the major species of seedcompetent tau in the brains of mice transgenic for human P301S tau. J Neurosci 36: 762-772.

Jang H, Boltz D, Webster RG, Smeyne RJ. 2009a. Viral parkinsonism. Biochim Biophys Acta 1792: 714-721.

Jang H, Boltz D, Sturm-Ramirez K, Shepherd KR, Jiao Y, Webster R, Smeyne RJ. 2009b. Highly pathogenic H5N1 influenza virus can enter the central nervous system and induce neuroinflammation and neurodegeneration. Proc Natl Acad Sci 18: 14063-14068.

Jones BE, Yang TZ. 1985. The efferent projections from the reticular formation and the locus coeruleus studied by anterograde and retrograde axonal transport in the rat. $J$ Comp Neurol 242: 56-92.

Jucker M, Walker LC. 2011. Pathogenic protein seeding in Alzheimer's disease and other neurodegenerative disorders. Ann Neurol 70: 532-540.

Jucker M, Walker LC. 2013. Self-propagation of pathogenic protein aggregates in neurodegenerative diseases. Nature 501: 45-51.

Kalaria RN, Stockmeier CA, Harik SI. 1989. Brain microvessels are innervated by locus ceruleus noradrenergic neurons. Neurosci Lett 97: 203-208.

Kanazawa T, Adachi E, Orimo S, Nakamura A, Mizusawa H, Uchihara T. 2011. Pale neurites, premature $\alpha$-synuclein aggregates with centripetal extension from axon collaterals. Brain Pathol 22: 67-78.

Kaufman SK, Diamond MI. 2013. Prion-like propagation of protein aggregation and related therapeutic strategies. Neurotherapeutics 10: 371-382.

Klos KJ, Ahlskog JE, Josephs KA, Apaydin H, Parisi JE, Boeve BF, DeLucia MW, Dickson DW. 2006. $\alpha$-Synuclein pathology in the spinal cords of neurologically asymptomatic aged individuals. Neurology 66: 1100-1102.

Kordower JH, Dodidya HB, Kordower AM, Terpstra B, Baumier K, Madhaven L, Sortwell C, Steece-Collier K, Collier TJ. 2011. Transfer of host-derived $\alpha$-synuclein to grafted dopaminergic neurons in the rat. Neurobiol Dis 43: $552-557$.

Kopeikina KJ, Hyman BT, Spires-Jones TL. 2012. Soluble forms of tau are toxic in Alzheimer's disease. Transl Neurosci 3: $223-233$.

Kovacech B, Skrabana R, Novak M. 2010. Transition of tau protein from disordered to misordered in Alzheimer's disease. Neurodeg Dis 7: 24-27.

Kuusisto E, Parkkinen L, Alafuzoff I. 2003. Morphogenesis of Lewy bodies: Dissimilar incorporation of $\alpha$-synuclein, ubiquitin, and p62. J Neuropathol Exp Neurol 62: 12411253.

Lamberts JT, Hildebrandt EN, Brundin P. 2015. Spreading of $\alpha$-synuclein in the face of axonal transport deficits in Parkinson's disease: A speculative synthesis. Neurobiol Dis 77: 276-283.

Lebouvier T, Chaumette T, Damier P, Coron E, Touchefeu Y, Vrignaud S, Naveilhan P, Galmiche JP, Bruley des Varannes S, Derkinderen P, et al. 2008. Pathological lesions in colonic biopsies during Parkinson's disease. Gut 57: 1741-1743.

Lebouvier T, Neunlist M, Bruley des Varannes S, Coron E, Brouard A, N'Guyen JM, Chaumette T, Tasselli M, Paillusson S, Flamand M, et al. 2010. Colonic biopsies to assess the neuropathology of Parkinson's disease and its relationship with symptoms. PLoS ONE 5: e12728.

Lee SJ, Desplats P, Sigurdson C, Tsigelny I, Masliah E. 2010. Cell-to-cell transmission of non-prion protein aggregates. Nat Rev Neurol 26: 702-706.

Lee HJ, Suk JE, Lee KW, Park SH, Blumbergs PC, Gai WP, Lee SJ. 2011. Transmission of synucleinopathies in the enteric nervous system of A53T $\alpha$-synuclein transgenic mice. Exp Neurobiol 20: 181-188.

Lehman NL. 2009. The ubiquitin proteosome system in neuropathology. Acta Neuropathol 118: 329-347. 
Tau and $\alpha$-Synuclein Dissemination in AD and PD

Liberski PP. 2012. Historical overview of prion diseases: A view from afar. Folia Neuropathol 50: 1-12.

Lim KH, Tan JMM. 2007. Role of the ubiquitin proteasome system in Parkinson's disease. BMC Biochem 8: S13.

Lingor P, Koch JC, Tönges L, Bähr M. 2012. Axonal degeneration as a therapeutic target in the CNS. Cell Tissue Res 349: $289-311$.

Liu L, Drouet V, Wu JW, Witter MP, Small SA, Clelland C, Duff K. 2012. Trans-synaptic spread of tau pathology in vivo. PLoS ONE 7: e31302.

Liubashina O, Jolkkonen E, Pitkänen A. 2000. Projections from the central nucleus of the amygdale to the gastric related areas of the dorsal vagal complex: A Phaseolus vulgaris-leucoagglutinin study in the rat. Neurosci Lett 291: 85-88.

Luk KC, Song C, O’Brien P, Stieber A, Branch JR, Brunden KR, Trojanowski JQ, Lee VM. 2009. Exogenous $\alpha$-synuclein fibrils seed the formation of Lewy body-like intracellular inclusions in cultured cells. Proc Natl Acad Sci 106: 20051-20056.

Luk KC, Kehm VM, Zhang B, O’Brien P, Trojanowski JQ, Lee VMY. 2012a. Intracerebral inoculation of pathological $\alpha$ synuclein initiates a rapidly progressive neurodegenerative $\alpha$-synucleinopathy in mice. J Exp Med 209: 975-986.

Luk KC, Kehm VM, Carroll J, Zhang B, O’Brien P, Trojanowski JQ, Lee VMY. 2012b. Pathological $\alpha$-synuclein transmission initiates Parkinson-like neurodegeneration in nontransgenic mice. Science 338: 949-953.

Malek N, Swallow D, Grosser KA, Anichtchik O, Spillantin M, Grosset DG. 2014. $\alpha$-Synuclein in peripheral tissues and body fluids as a biomarker for Parkinson's diseaseA systematic review. Acta Neurol Scand 130: 59-72.

Marien MR, Colpaert FC, Rosenquist AC. 2004. Noradrenergic mechanisms in neurodegenerative diseases: A theory. Brain Res Rev 45: 38-78.

Markesbery WR, Jicha GA, Liu H, Schmitt FA. 2009. Lewy body pathology in normal elderly subjects. J Neuropathol Exp Neurol 68: 816-822.

Masuda-Suzukake M, Nonaka T, Hosokawa M, Oikawa T, Arai T, Akiyama H, Mann DMA, Hasegawa M. 2013. Prion-like spreading of pathological $\alpha$-synuclein in brain. Brain 136: $1128-1138$.

Masters CL, Selkoe DJ. 2012. Biochemistry of amyloid $\beta$-protein and amyloid deposits in Alzheimer's disease. Cold Spring Harb Perspect Med 2: a006262.

McBride PA, Schulz-Schaeffer WJ, Donaldson M, Bruce M, Diringer H, Kretzschmar HA, Beekes M. 2001. Early spread of scrapie from the gastrointestinal tract to the central nervous system involves autonomic fibers of the splanchnic and vagus nerves. J Virol 75: 9320-9327.

McCann H, Cartwright H, Halliday GM. 2015. Neuropathology of $\alpha$-synuclein propagation and Braak hypothesis. Mov Disord 31: 152-160.

Melki R. 2015. Role of different $\alpha$-synuclein strains in synucleinopathies, similarities with other neurodegenerative diseases. J Parkinson's Dis 5: 217-227.

Mirbaha H, Holmes BB, Sanders DW, Bieschke J, Diamond MI. 2015. Tau trimers are the minimal propagation unit spontaneously internalized to seed intracellular aggregation. J Biol Chem 290: 14893-14903.
Miwa H, Kubo T, Susuki A, Kondo T. 2006. Intragastric proteasome inhibition induces $\alpha$-synuclein-immunopositive aggregations in neurons in the dorsal motor nucleus of the vagus in rats. Neurosci Lett 401: 146-149.

Morrison JH, Foote SL, O'Connor D, Bloom FE. 1982. Laminar, tangential and regional organization of the nordrenergic innervation of monkey cortex: Dopamin- $\beta$ hydroxylase immunohistochemistry. Brain Res Bull 9: 309-319.

Mougenot AL, Nicot S, Bencsik A, Morignat E, Vechère J, Lakhdar L, Legastelois S, Baron T. 2012. Prion-like acceleration of a synucleinopathy in a transgenic mouse model. Neurobiol Aging 33: 2225-2228.

Nieuwenhuys R. 1996. The greater limbic system, the emotional motor system and the brain. Progr Brain Res 107: $551-580$.

Nieuwenhuys R. 1999. Structure and organisation of fibre systems. In The central nervous system of vertebrates, Vol. 1 (ed. Nieuwenhuys R, Ten Donkelaar JH, Nicholson C), pp 113-157. Springer, Berlin.

Nonaka T, Watanabe S, Iwatsubo T, Hasegawa M. 2010. Seeded aggregation and toxicity of $\alpha$-synuclein and tau: Cellular models of neurodegenerative diseases. J Biol Chem 285: 34885-34898.

O’Donnell J, Zeppenfeld D, McConnell E, Pena S, Nedergaard M. 2012. Norepinephrine: A neuromodulator that boosts the function of multiple cell types to optimize CNS performance. Neurochem Res 37: 2496-2512.

Olanow CW, Brundin P. 2013. Parkinson's disease and $\alpha$ synuclein: Is Parkinson's disease a prion-like disorder? Mov Disord 28: 31-40.

Olanow CW, McNaught K. 2006. Ubiquitin-proteasome system and Parkinson's disease. Mov Disord 21: $1806-$ 1823.

Olanow CW, McNaught K. 2011. Parkinson's disease, proteins, and prions: Milestones. 2011. Mov Disord 26: 1056-1071.

Orimo S, Uchihara T, Nakamura A, Mori F, Kakita H, Wakabayashi K, Takahashi H. 2008. Axonal $\alpha$-synuclein aggregates herald centripetal degeneration of cardiac sympathetic nerve in Parkinson's disease. Brain 131: 642650.

Ozcelik S, Sprenger F, Skachokova Z, Fraser G, Abramowski D, Clavaguera F, Probst A, Frank S, Müller M, Staufenbiel $\mathrm{M}$, et al. 2016. Co-expression of truncated and full-length tau induces severe neurotoxicity. Mol Pychiatry doi: 10.1038/mp.2015.228.

Pan T, Kondo S, Le W, Jankovic J. 2008. The role of autophagy-lysosome pathway in neurodegeneration associated with Parkinson's disease. Brain 131: 1969-1978.

Pan-Montojo F, Anichtchik O, Dening Y, Knels L, Pursche S, Jung R, Jackson S, Gille G, Spillantini MG, Reichmann H, et al. 2010. Progression of Parkinson's disease pathology is reproduced by intragastric administration of rotenone in mice. PLoS ONE 5: 8762.

Pan-Montojo F, Schwarz M, Winkler C, Arnhold M, O'Sullivan GA, Pal A, Said J, Marisco V, Verbavatz JM, RodrigoAngulo M, et al. 2012. Environmental toxins trigger PDlike progression via increased $\alpha$-synuclein release from enteric neurons in mice. Sci Rep 2: 898. 
Parent M, Parent A. 2010. Substantia nigra and Parkinson's disease: A brief history of their long and intimate friendship. Can J Neurol Sci 37: 313-319.

Pearce RK, Hawkes CH, Daniel SE. 1995. The anterior olfactory nucleus in Parkinson's disease. Mov Disord 10: 429-434.

Pearson RC. 1996. Cortical connections and the pathology of Alzheimer's disease. Neurodegeneration 5: 429-434.

Pearson RC, Powell TP. 1989. The neuroanatomy of Alzheimer's disease. Rev Neurosci 2: 101-122.

Pearson RC, Esiri MM, Hiorns RW, Wilcock GK, Powell TP. 1985. Anatomical correlates of the distribution of the pathological changes in the neocortex of Alzheimer's disease. Proc Natl Acad Sci 82: 4531-4534.

Peelaerts W, Bousset L, Van der Peren A, Moskalyuk A, Pulizzi R, Giugliano M, Van den Haute C, Melki R, Baekelandt V. 2015. $\alpha$-Synuclein strains cause distinct synucleinopathies after local and systemic administration. Nature 522: 340-344.

Polymenidou M, Cleveland DW. 2012. Prion-like spread of protein aggregates in neurodegeneration. J Exp Med 209: 889-893.

Pooler AM, Polydoro M, Wegmann S, Nicholls SB, SpiresJones TL, Hyman BT. 2013. Propagation of tau pathology in Alzheimer's disease: Identification of novel therapeutic targets. Alzheimers Res Ther 5: 49-57.

Pouclet H, Lebouvier T, Coron E, Bruley des Varannes S, Rouaud T, Roy M, Neunlist M, Derkinderen. 2011. A comparison between rectal and colonic biopsies to detect Lewy pathology in Parkinson's disease. Neurobiol Dis 45: 305-309.

Prusiner SB. 1982. Novel proteinaceous infectious particles cause scrapie. Science 216: 136-144.

Prusiner SB. 2012. Cell biology. A unifying role for prions in neurodegenerative diseases. Science 336: 1511-1513.

Prusiner SB. 2013. Biology and genetics of prions causing neurodegeneration. Annu Rev Genet 47: 601-623.

Prusiner SB, Woerman AL, Mordes DA, Watts JC, Rampersaud R, Berry DB, Patel S, Oehler A, Lowe JK, Kravitz SN, et al. 2015. Evidence for $\alpha$-synuclein prions causing multiple system atrophy in humans with parkinsonism. Proc Natl Acad Sci 112: E5308-E5317.

Quilty MC, King AE, Gai WP, Pountney DL, West AK, Vickers JC, Dickson TC. 2006. $\alpha$-Synuclein is upregulated in neurons in response to chronic oxidative stress and is associated with neuroprotection. Exp Neurol 199: 249256.

Rapoport SI. 1988. Brain evolution and Alzheimer's disease. Rev Neurol (Paris) 144: 79-90.

Rapoport SI. 1989. Hypothesis: Alzheimer's disease is a phylogenetic disease. Med Hypotheses 29: 147-150.

Rapoport SI. 1990. Integrated phylogeny of the primate brain, with special reference to humans and their diseases. Brain Res Rev 15: 267-294.

Rapoport SI. 1999. How did the human brain evolve? A proposal based on new evidence from in vivo imaging during attention and ideation. Brain Res Bull 50: 149_ 165.

Recasens A, Dehay B, Bové J, Carballo-Carbajal I, Dovero S, Pérez-Villalba A, Fernagut PO, Blesa J, Parent A, Perier C, et al. 2014. Lewy body extracts from Parkinson disease brains trigger $\alpha$-synuclein pathology in neurodegeneration in mice and monkeys. Ann Neurol 75: 351-362.

Rey NL, Petit GH, Bousset L, Melki R, Brundin P. 2013. Transfer of human $\alpha$-synuclein from the olfactory bulb to interconnected brain regions in mice. Acta Neuropathol 126: $555-573$.

Richards WG, Sugarbaker DJ. 1995. Neuronal control esophageal function. Chest Surg Clin North Am 5: $157-$ 171.

Rubinsztein DC. 2006. The roles of intracellular proteindegradation pathways in neurodegeneration. Nature 443: $780-786$.

Sacino AN, Brooks M, Thomas MA, McKinney AB, Lee LS, Regenhardt RW, McGarvey NH, Ayers JI, Notterpek L, Borchelt DL, et al. 2014. Intramuscular injection of $\alpha$-synuclein induces CNS $\alpha$-synuclein pathology and a rapid-onset motor phenotype in transgenic mice. Proc Natl Acad Sci 111: 10732-10737.

Saha AR, Hill J, Utton MA, Assuni AA, Ackerley S, Grierson AJ, Miller CC, Davies AM, Buchman VL, Anderton BH, et al. 2004. Parkinson's disease $\alpha$-synuclein mutations exhibit defective axonal transport in cultured neurons. J Cell Sci 117: 1017-1024.

Samuels ER, Szabadi E. 2009. Functional neuroanatomy of the noradrenergic locus coeruleus: Its roles in the regulation of arousal and autonomic function. Part I: Principles of functional organization. Curr Neuropharmacol 6: 235-253.

Sanders DW, Kaufman SK, DeVos SL, Sharma AM, Mirbaha H, Li A, Barker SJ, Foley AC, Thorpe JR, Serpell LC, et al. 2014. Distinct tau prion strains propagate in cells and define different tauopathies. Neuron 82: 1271-1288.

Saper CB, Weiner BH, German DC. 1987. Axonal and transneuronal transport in the transmission of neurological disease: Potential role in system degenerations, including Alzheimer's disease. Neuroscience 23: 389-398.

Sara SJ. 2009. The locus coeruleus and noradrenergic modulation of cognition. Nature Rev Neurosci 10: 211-223.

Shannon KM, Deshavarzian A, Mutlu E, Dodiya HB, Daian D, Jaglin JA, Kordower JH. 2012. $\alpha$-Synuclein in colonic submucosa in early untreated Parkinson's disease. Mov Disord 27: 709-715.

Shipley MT, Halloran FJ, de la Torre J. 1985. Surprisingly rich projection from the locus coeruleus to the olfactory bulb in the rat. Brain Res 329: 294-299.

Sims KS, Williams RS. 1990. The human amygdaloid complex: A cytologic and histochemical atlas using Nissl, myelin, acetylcholinesterase and nicotinamide adenine dinucleotide phosphate diaphorese staining. Neuroscience 36: 449-472.

Smethurst P, Sidle KC, Hardy J. 2015. Review: Prion-like mechanisms of transactive response DNA binding protein of $43 \mathrm{kDa}$ (TPD-43) in amyotrophic lateral sclerosis (ALS). Neuropathol Appl Neurol 41: 578-597.

Spillantini MG, Schmidt ML, Lee VM, Trojanowski JQ, Jakes R, Goedert M. 1997. $\alpha$-Synuclein in Lewy bodies. Nature 388: 839-840.

Stokholm MS, Danielsen EH, Hamilton-Dutoit SJ, Borghammer P. 2016. Pathological $\alpha$-synuclein in gastrointestinal tissues from prodromal Parkinson's disease patients. Ann Neurol 79: 940-949. 
Tau and $\alpha$-Synuclein Dissemination in AD and PD

Stokin GB, Goldstein LS. 2006. Axonal transport and Alzheimer's disease. Ann Rev Biochem 75: 607-627.

Supattapone S. 2015. Expanding the prion disease repertoire. Proc Natl Acad Sci 112: 11748-11749.

Svensson E, Horváth-Puhó E, Thomsen RW, Djurhuus JC, Pedersen L, Borghammer P, Sørensen HT. 2015. Vagotomy and subsequent risk of Parkinson's disease. Ann Neurol 78: $522-529$.

Sydow A, Van der Jeugd A, Zheng F, Ahmed T, Balschun D, Petrova O, Drexler D, Zhou L, Rune G, Mandelkow E, et al. 2011. Tau-induced defects in synaptic plasticity, learning, and memory are reversible in transgenic mice after switching off the toxic Tau mutant. J Neurosci 31: 2511-2525.

Tai HC, Serrano-Pozo A, Hashimoto T, Frosch MP, SpiresJones TL, Hyman BT. 2012. The synaptic accumulation of hyperphosphorylated tau oligomers in Alzheimer disease is associated with dysfunction of the ubiquitin-proteasome system. Am J Pathol 181: 1426-1435.

Takeda S, Yamazaki K, Miyakawa T, Arai H. 1993. Parkinson's disease with involvement of the parasympathetic ganglia. Acta Neuropathol 86: 397-398.

Tofaris GK, Spillantini MG. 2007. Physiological and pathological properties of $\alpha$-synuclein. Cell Mol Life Sci 64: 2194-2201.

Tsigelny IF, Sharikov Y, Wrasidio W, Gonzalez T, Desplats PA, Crews L, Spencer B, Masliah E. 2012. Role of $\alpha$-synuclein penetration into the membrane in the mechanisms of oligomer pore formation. FEBS J 279: 1000-1013.

Tuttle MD, Comellas G, Nieuwkoop AJ, Covell DJ, Berthold DA, Kloepper KD, Courtney JM, Kim JK, Barclay AM, Kendall A, et al. 2016. Solid-state NMR structure of a pathogenic fibril of full-length human $\alpha$-synuclein. Nat Struct Mol Biol 23: 409-415.

Ulusoy A, Rusconi R, Perez-Revuelta BI, Musgrove RE, Helwig M, Winzen-Reichert B, Di Monte DA. 2013. Caudo-rostral brain spreading of $\alpha$ synuclein through vagal connections. EMBO Mol Med 5: 1051-1059.

Upadhya SC, Hegde AN. 2007a. Role of the ubiquitin proteasome system in Alzheimer's disease. BMC Biochem 8: S12.

Upadhya SC, Hegde AN. 2007b. The ubiquitin-proteasome pathway in health and disease of the nervous system. Trends Neurosci 30: 587-595.

Utton MA, Connell J, Asuni AA, van Slegtenhorst M, Hutton M, de Silva R, Lees AJ, Miller CC, Anderton BH. 2002. The slow axonal transport of the microtubule-associated protein tau and the transport rates of different isoforms and mutants in cultured neurons. Neurosci 22 6394-6400.

Van Ba AT, Imberdis T, Perrier V. 2013. From prion disease to prion-like propagation mechanisms of neurodegenerative diseases. Int J Cell Biol 2013: 975832.

van de Berg WD, Hepp DH, Dijkstra AA, Rozemuller JA, Berendse HW, Foncke E. 2012. Patterns of $\alpha$-synuclein pathology in incidental cases and clinical subtypes of Parkinson's disease. Parkinsonism Relat Disord 18: S28-S30.

Vella LJ, Sharples RA, Lawson VA, Masters CL, Cappai R, Hill AF. 2007. Packaging of prions into exosomes is associated with a novel pathway of PrP processing. J Pathol 211: $582-590$.
Volpicelli-Daley LA, Luk KC, Patel PT, Tanik SA, Riddle DM, Stieber A, Meaney DF, Trojanowki JQ, Lee VM. 2011. Exogenous $\alpha$-synuclein fibrils induce Lewy body pathology leading to synaptic dysfunction and neuron death. Neuron 72: 57-71.

Volpicelli-Daley LA, Gamble KL, Schultheiss CE, Riddle DM, West AB, Lee VM. 2014. Formation of $\alpha$-synuclein Lewy neurite-like aggregates in axons impedes the transport of distinct endosomes. Mol Biol Cell 25: 4010-4023.

von Bergen M, Barghorn S, Biernat J, Mandelkow EM, Mandelkow E. 2005. Tau aggregation is driven by a transition from random coil to $\beta$ sheet structure. Biochim Biophys Acta 1739: 158-166.

Wakabayashi K, Takahashi H. 1997a. Neuropathology of autonomic nervous system in Parkinson's disease. Eur Neurol 38 (Suppl 2): 2-7.

Wakabayashi K, Takahashi H. 1997b. The intermediolateral nucleus and Clarke's column in Parkinson's disease. Acta Neuropathol 94: 287-289.

Wakabayashi K, Takahashi H, Takeda S, Ohama E, Ikuta F. 1988. Parkinson's disease: The presence of Lewy bodies in Auerbach's and Meissner's plexuses. Acta Neuropathol 76: 217-221.

Wakabayashi K, Takahashi H, Takeda S, Ohama E, Ikuta F. 1989. Lewy bodies in the enteric nervous system in Parkinson's disease. Arch Histol Cytol 52 (Suppl): 191-194.

Wakabayashi K, Takahashi H, Ohama E, Ikuta F. 1990. Parkinson's disease: An immunohistochemical study of Lewy body-containing neurons in the enteric nervous system. Acta Neuropathol 79: 581-583.

Wakabayashi K, Takahashi H, Ohama E, Takeda S, Ikuta F 1993. Lewy bodies in the visceral autonomic nervous system in Parkinson's disease. Adv Neurol 60: 609-612.

Wakabayashi K, Hansen LA, Masliah E. 1995. Cortical Lewy body-containing neurons are pyramidal cells: Laser confocal imaging of double-immunolabeled sections with anti-ubiquitin and SMI32. Acta Neuropathol 89: 404-408.

Walker LC, Jucker M. 2015. Neurodegenerative diseases: Expanding the prion concept. Ann Rev Neurosci 38: 87-103.

Walker LC, Diamond MI, Duff KE, Hyman BT. 2012. Mechanisms of protein seeding in neurodegenerative diseases. JAMA Neurol 70: 304-310.

Walsh DM, Selkoe DJ. 2016. A critical appraisal of the pathogenic protein spread hypothesis of neurodegeneration. Nat Rev Neurosci 17: 251-260.

Watts JC, Giles K, Oehler A, Middletond L, Dexter DT, Gentleman SM, DeArmond SJ, Prusiner SB. 2013. Transmission of multiple system atrophy prions to transgenic mice. Proc Natl Acad Sci 110: 19555-19560.

Woerman AL, Stöhr J, Aoyagi A, Rampersaud R, Krejciovaa Z, Watts JC, Ohyama T, Patel S, Widjaja K, Oehler A, et al. 2015. Propagation of prions causing synucleinopathies in cultured cells. Proc Natl Acad Sci 112: E4949E4958.

Wu JW, Herman M, Liu I, et al. 2013. Small misfolded tau species are internalized via bulk endocytosis and anterogradely and retrogradely transported in neurons. J Biol Chem 288: 1856-1870. 


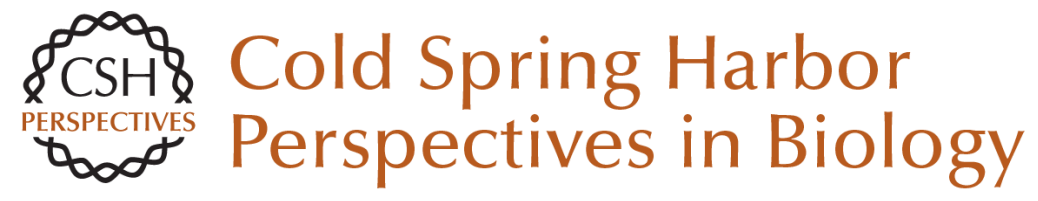

\section{Potential Pathways of Abnormal Tau and $\alpha$-Synuclein Dissemination in Sporadic Alzheimer's and Parkinson's Diseases}

Heiko Braak and Kelly Del Tredici

Cold Spring Harb Perspect Biol 2016; doi: 10.1101/cshperspect.a023630 originally published online August 31, 2016

\section{Subject Collection Prion Biology}

\section{Genetic PrP Prion Diseases}

Mee-Ohk Kim, Leonel T. Takada, Katherine Wong, et al.

Neurodegenerative Disease Transmission and Transgenesis in Mice Brittany N. Dugger, Daniel P. Perl and George A. Carlson

Toward the Atomic Structure of PrPSc Jose A. Rodriguez, Lin Jiang and David S. Eisenberg

Bioassays and Inactivation of Prions Kurt Giles, Amanda L. Woerman, David B. Berry, et al.

Functional Prions in the Brain Joseph B. Rayman and Eric R. Kandel

The Amyloid Phenomenon and Its Links with Human Disease Christopher M. Dobson

Tau Positron Emission Tomography Imaging Hartmuth C. Kolb and José Ignacio Andrés

Prion-Like Polymerization in Immunity and Inflammation

Xin Cai, Hui Xu and Zhijian J. Chen
Clinical Neurology and Epidemiology of the Major

Neurodegenerative Diseases

Michael G. Erkkinen, Mee-Ohk Kim and Michael D. Geschwind

Prion Properties of SOD1 in Amyotrophic Lateral

Sclerosis and Potential Therapy Caroline Sibilla and Anne Bertolotti

Mapping Neurodegenerative Disease Onset and

Progression William W. Seeley

Erratum: Functional Prions in the Brain Joseph B. Rayman and Eric R. Kandel

Pathology of Neurodegenerative Diseases Brittany N. Dugger and Dennis W. Dickson

TIA-1 Is a Functional Prion-Like Protein Joseph B. Rayman and Eric R. Kandel

Molecular Genetics of Neurodegenerative

Dementias

Flora I. Hinz and Daniel H. Geschwind

Cross- $\beta$ Polymerization of Low Complexity

Sequence Domains

Masato Kato and Steven L. McKnight

For additional articles in this collection, see http://cshperspectives.cshlp.org/cgi/collection/

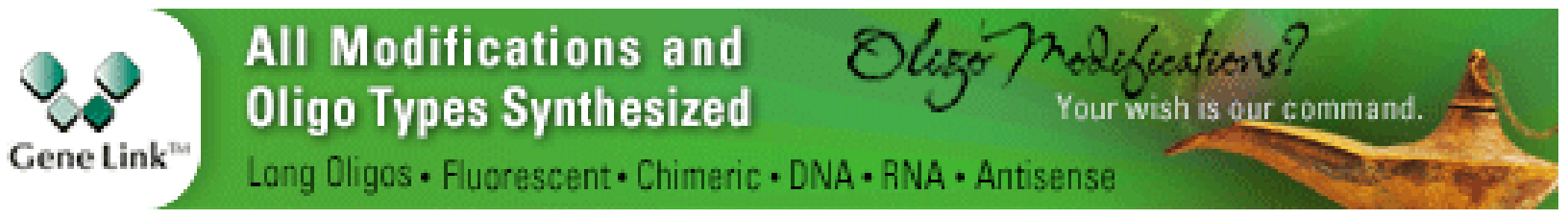


For additional articles in this collection, see http://cshperspectives.cshlp.org/cgi/collection/

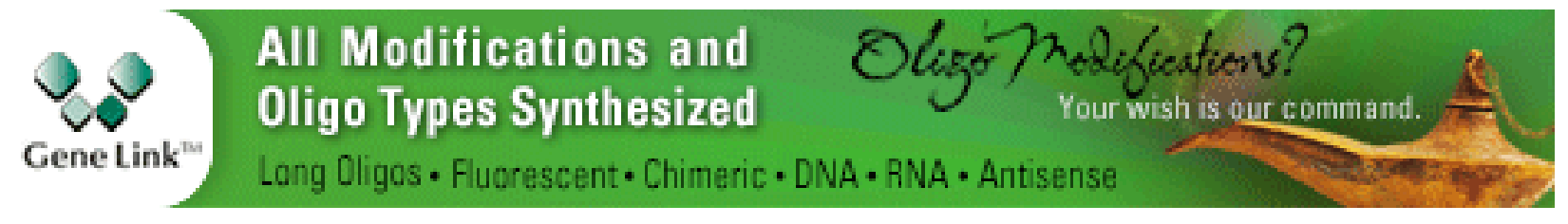

Copyright @ 2016 Cold Spring Harbor Laboratory Press; all rights reserved 